\title{
Role of Fibrinolytic Enzymes in Anti-Thrombosis Therapy
}

\author{
Farwa Altaf ${ }^{1}$, Shourong $\mathrm{Wu}^{1,2 *}$ and Vivi Kasim ${ }^{1,2 *}$ \\ ${ }^{1}$ The Key Laboratory of Biorheological Science and Technology, Ministry of Education, College of Bioengineering, Chongqing \\ University, Chongqing, China, ${ }^{2}$ The 111 Project Laboratory of Biomechanics and Tissue Repair, College of Bioengineering, \\ Chongqing University, Chongqing, China
}

\section{OPEN ACCESS}

Edited by:

Wangsa Tirta Ismaya,

Dexa Medica, Indonesia

Reviewed by:

Nikhat Jamal Siddiqi,

King Saud University, Saudi Arabia

Md. Murshidul Ahsan,

Yeungnam University, South Korea

${ }^{*}$ Correspondence:

Vivi Kasim

vivikasim@cqu.edu.cn

Shourong Wu

shourongwu@cqu.edu.cn

Specialty section:

This article was submitted to

Protein Chemistry and Enzymology,

a section of the journal

Frontiers in Molecular Biosciences

Received: 14 March 2021

Accepted: 10 May 2021

Published: 28 May 2021

Citation:

Altaf F, Wu S and Kasim V (2021) Role of Fibrinolytic Enzymes in Anti-

Thrombosis Therapy.

Front. Mol. Biosci. 8:680397.

doi: 10.3389/fmolb.2021.680397
Thrombosis, a major cause of deaths in this modern era responsible for $31 \%$ of all global deaths reported by WHO in 2017, is due to the aggregation of fibrin in blood vessels which leads to myocardial infarction or other cardiovascular diseases (CVDs). Classical agents such as anti-platelet, anti-coagulant drugs or other enzymes used for thrombosis treatment at present could leads to unwanted side effects including bleeding complication, hemorrhage and allergy. Furthermore, their high cost is a burden for patients, especially for those from low and middle-income countries. Hence, there is an urgent need to develop novel and low-cost drugs for thrombosis treatment. Fibrinolytic enzymes, including plasmin like proteins such as proteases, nattokinase, and lumbrokinase, as well as plasminogen activators such as urokinase plasminogen activator, and tissue-type plasminogen activator, could eliminate thrombi with high efficacy rate and do not have significant drawbacks by directly degrading the fibrin. Furthermore, they could be produced with high-yield and in a cost-effective manner from microorganisms as well as other sources. Hence, they have been considered as potential compounds for thrombosis therapy. Herein, we will discuss about natural mechanism of fibrinolysis and thrombus formation, the production of fibrinolytic enzymes from different sources and their application as drugs for thrombosis therapy.

Keywords: thrombosis therapy, thrombolytic drugs, plasminogen activators, proteases, fibrinolytic enzymes

\section{INTRODUCTION}

In 2017, cardiovascular diseases (CVDs) caused 17.7 million deaths globally (CVDs) (Yusuf et al., 2020). Thrombosis is the formation of blood clot in both artery and venous arterial or venous circulation. Arterial thrombosis is caused mainly by accumulation of platelets, fibrin, and thrombin, which could leads to the formation and spreading of atherosclerotic plaque (Boos and Lip, 2006), and is the major cause of most cases of heart attack (myocardial infarction) (Mackman, 2008).

Fibrinogen is a large soluble plasma glycoprotein produced and released by the liver, and converted into polymeric fibrin by thrombin during damage to vascular system. Initiation of the blood clotting process occurs at the wound site when platelets are aggregated and a proteolytic cascade mechanism to convert fibrinogen into fibrin is started (Doolittle, 2010; Weisel and Litvinov, 2017). Normally these clots are hydrolyzed by plasmin; however, aberrant control of the hydrolysis process could cause hyperfibrinogenemia, which, subsequently, leads to a variety of thrombotic diseases such as stroke (Danesh et al., 2005; Chelluboina and Vemuganti, 2019), abdominal aortic aneurysm (Parry et al., 2009; Kapetanios et al., 2019), peripheral vascular disease (Altes et al., 2018), pulmonary embolism (Klovaite et al., 2013), and cardiovascular disease (CVD) (Tatli et al., 2009; Liu et al., 2020). 
Various anti-coagulants like heparin, fondaparinux, idraparinux (Gross and Weitz, 2008), warfarin (Kneeland and Fang, 2010), and rivaroxaban have been used for treating thrombosis; however, they could also cause side effects such as bleeding, which is the major problem in all anti-coagulants, hemorrhages (Stam et al., 2002), and long term adherence. Furthermore, solving uncertainty about their dosing and expensive process are also in urgent (Bauer, 2013; Burgazli et al., 2013). Thrombolytic agents such as urokinase and plasminogen activators have been extensively used for treating thrombosis; however, in addition to their high costs, they might also caused internal hemorrhage within the intestinal tract when administered orally (Flemmig and Melzig, 2012; Kotb, 2012). Likewise, anti-platelets such as aspirin, prasugrel, and ticagrelo which are used to prevent clot formation, could also bleedings, including intracranial haemorrhage, skin bruising, and gastrointestinal bleeding (Swan et al., 2020). These draw backs have evoked researchers to look for safer and cheaper resources (Flemmig and Melzig, 2012; Kotb, 2012; Kotb et al., 2015).

Fibrinolytic enzymes are involved in the degradation of fibrin clots, by either catalyzing fibrin degradation process or by transforming the inactive plasminogen into active plasmin, thus re-establishing the normal blood vascular architecture (Krishnamurthy et al., 2018). They are largely proteases, which are involved in the total hydrolysis of proteins, and can be produced from all living cells especially bacteria. On the basis of their site of actions, proteases could be divided into two groups: endopeptidases and exopeptidases; while on the bases of the distinct functional groups located at the active site, they could be classified into five types, namely cystein proteases, serine proteases, threonine proteases, metalloproteases and aspartic proteases (Flemmig and Melzig, 2012). Fibrinolytic enzymes have been discovered from different sources such as microorganisms, plants, animals and fermented products, and among them, the most important sources are micoorganisms, especially genous Bacillus from the traditional fermented foods (Mine et al., 2005). Due to their property of dissolving the thrombus by directly degrading the fibrin at high rate, microbial fibrinolytic enzymes have the potential to be used as drugs for treating thrombosis and other related diseases (Kotb, 2012). In this review, we will outline the mechanisms of fibrinolysis, thrombus formation, isolation of fibrinolytic enzymes from different sources and their role in thrombus degradation.

\section{THROMBUS FORMATION}

Injury to the wall of blood vessel and eruption of blood from the circulation triggers the onset of thrombus formation through the processes including formation of atherosclerotic plaque, activation of platelets and coagulation pathways (Furie and Furie, 2008; Asada et al., 2018). The composition of thrombi is different in arteries and veins, venous thrombi are red clots due to abundance of fibrin and red blood cells, while arterial thrombi are white clots as they mainly composed of platelets aggregates (Franchini and Mannucci, 2008).
Activation of endothelial cells upon aggregation of cholesterol containing low density lipoprotein (LDL) serves as the initiation atherosclerotic process. Endothelial cells express chemokines and leukocyte adhesion molecules that boost the recruitment of T cells and monocytes to the site. Monocytes will then differentiate into macrophages and this will upregulate the expression level of pattern recognition receptors, including scavenger and toll-like receptors (TLRs) (Lippi et al., 2011). These pattern recognition receptors will in turn enhance the uptake of lipoproteins, which subsequently lead to the generation of foam cells. Binding of ligand to TLRs transfer macrophage-activating signals that results in the discharge of cytokines, proteases and other vasoactive molecules (Hodgkinson and Ye, 2011). T lymphocytes produce proinflammatory cytokines that interact with local antigens and support T-helper-1 cell responses within the atherosclerotic lesion, which further promote the plaque growth and enhance local inflammation (Lundberg and Hansson, 2010). Prolonged local inflammation results in the disruption and proteolysis of atherosclerotic plaque, leading to plaque erosion and rupture (Lippi et al., 2011).

Atherosclerotic plaques contain foam cells, tissue factor (TF), lipid droplets, necrotic cell debris and matrix constituents as well as other platelets activating molecules such as fibrinogen, fibrin, vitronectin, thrombospondin, von Willebrand factor (VWF, a plasma protein carrier for factor VIII essential for adhesion of platelets to the vessel wall), fibronectin, stromal derived factor 1 , various types of collagens, LDLcholesterol sulfate and oxidized LDL. These molecules actively stimulate adhesion and accumulation of platelets along with emission of their heavy granules. Human atherosclerotic plaques induce the formation of arterial thrombi through a complex process involving platelets aggregation and accumulation, as well as the activation of blood coagulation, which subsequently leads to the formation of thrombus (Reininger Armin et al., 2010; Lippi et al., 2011).

Platelet aggregate formation is initiated by the interaction of platelet surface receptors glycoprotein Ib-IX-V (GPIb-IX-V, cluster of adhesive receptors on platelets) and glycoprotein VI (GPVI, a collagen receptor) with collagenous plaque components such as VWF and collagen, respectively. Then a shift in the conformation of integrins on the platelets triggers the initial phase of platelet accumulation, involving various factors such as glycoprotein IIb/IIIa (GPIIb/IIIa, also known as $\mathrm{GP}_{\alpha} \mathrm{I} / \beta \mathrm{III}$ or integrin $\alpha_{3} \beta_{2}$ ), glycoprotein-receptor-Ia/IIa (GPIa/IIa also known as integrin $\alpha_{2} \beta_{1}$ for collagen binding), adenosine diphosphate (ADP), and thromboxance $\mathrm{A}_{2}\left(\mathrm{TXA}_{2}\right)$. GIIb/IIIa is a fibrinogen receptor attaches with VWF and fibrinogen and mediates tight adhesion, spreading, coagulation activity, and accumulation of platelets; while GPIa/IIa mediates collagen-platelet binding under low-shear-rate conditions, such as those near an atherosclerotic plaque, and strengthen the connection between collagen and glycoprotein VI (GPVI). Then ADP promotes platelets to undergo shape change, leading to the release of granule contents and platelets aggregation. Furthermore, thromboxance A2 $\left(\mathrm{TXA}_{2}\right)$ acts as a positive feedback regulator that activates and recruits more platelets to the main hemostatic plug (Furie and Furie, 2008; Reininger Armin et al., 2010; Lippi et al., 2011). 
After activation and recruitment of platelets, blood coagulation will be initiated by binding of tissue factor to factor VIIa (FVIIa) and thrombin burst, which encompasses the transformation of inactive proenzymes to into their respective serine proteases in a sequential manner, leading to thrombin generation (Reininger Armin et al., 2010). Thrombin burst will then be formed in the presence of factor XI (FXI), factor $\mathrm{X}$ (FX), and factor IX (FIX), which act as a physiological amplificatory mechanism propagating thrombin generation. During this, fibrin produced by the enzymatic action of factor $\mathrm{X}$ on fibrinogen and TAFI (thrombin-activatable fibrinolysis inhibitor) will also downregulate fibrinolysis by weakening the plasmin mediated fibrin breakdown to promote thrombin formation (Lippi et al., 2011). Together, thrombus formation is a complex, multifactors-regulated process involving the synthesis of atherosclerotic plaques, platelets aggregation, and blood coagulation.

\section{FIBRINOLYSIS}

Fibrinolysis is the enzymatic breakdown of fibrin network of blood clots by fibrinolytic enzymes (Bannish et al., 2017). This process is regulated by two steps: first, tissue plasminogen activator (tPA) and urokinase plasminogen activator (uPA) convert plasminogen into serine protease plasmin and second, fibrin is broken down into fibrin degradation products, thus restoring the bood flow by dissolving the thrombus (Gue and Gorog, 2017). These processes are regulated by the engagement of substrates, cofactors, activators, receptors and inhibitors, which work synergistically to guarantee the fluidity of blood (CesarmanMaus and Hajjar, 2005; Bannish et al., 2017).

The major fibrinolytic protease is plasmin formed by conversion of plasminogen by both tissue plasminogen activator (tPA) and urokinase plasminogen activator (uPA). Through a positive feedback mechanism, plasmin cleaves the single chain of both uPA and tPA into two more active polypeptide chains. Plasmin generation is increased by the degradation of fibrin, the major substrate of plasmin, by binding both tissue plasminogen activator and plasminogen on its surface (Cesarman-Maus and Hajjar, 2005). In the absence of fibrin, tPA acts as a weak activator of plasminogen, while the presence of fibrin significantly increases the affinity between tPA and plasminogen, and thus enhances the catalytic efficiency of tPA in activating plasminogen. After being formed, plasmin produces soluble degradation products by cleaving the fibrin. The "kringles" 1 and 4 domains of plasminogen and 2 of tPA carry lysine binding sites, which enhance its binding to fibrin, thus causing the increased plasmin production and removal of fibrin (Kolev and Machovich, 2003; Cesarman-Maus and Hajjar, 2005).

In healthy person, the regulation of fibrinolysis is achieved by certain regulators including fibrinolysis inhibitors and plasminogen activator inhibitor. Fibrinolysis inhibitors, such as thrombin activatable fibrinolysis inhibitor (TAFI), and lysin analogues including tranexamic acid and epsilon aminocaproic acid (Bridge et al., 2014). TAFI reduces the fibrinogen and fibrin binding, a2-antiplasm forms complex with plasmin, increases adsorption of PLG on fibrin and crosslinks FXIIIa, a clotting factor that produce the cross-links between fibrin strands and inhibitors such as TAFI and a2-antiplasm; while PAI-1, a plasminogen activator inhibitor whose production and binding ability to plasminogen could be enhanced by lipoprotein (a), inhibits uPA and tPA (Gue and Gorog, 2017).

Together, fibrinolysis is crucial for anti-thrombin therapy, and plasmin is the major enzyme responsible for fibrinolysis. While many fibrinolytic enzymes have been used for clinical treatment, natural sources for obtaining this enzyme as described below might be potential as sources for fibrinolytic enzyme due to their activity and low production costs.

\section{MICROORGANISMS AS SOURCES OF FIBRINOLYTIC ENZYMES}

Microorganisms are the most important and cheap source of fibrinolytic enzymes, and many of them, such as Streptokinase and Staphylokinase, which were isolated from Streoptococcus hemolyticus and Streptococcus aureus, are effective in thrombolytic therapy (Collen and Lijnen, 1994). Since then, many fibrinolytic enzymes from various microbial and nonmicrobial sources have been discovered in succession.

Bacteria that belong to genus bacillus are the most important source of fibrinolytic enzymes (Table 1). Since their discovery, many studies have been performed to optimize the production conditions of fibrinolytic enzyme to increase their yield by using different methods of fermentation, including solid-state, and submerged fermentation (Vijayaraghavan et al., 2017; Al Farraj et al., 2020; Che et al., 2020), mutagenesis (Naveena et al., 2012; Raju and Divakar, 2013a), recombination (Che et al., 2020), statistical approaches (Chandramohan et al., 2019; Joji et al., 2019) and gene cloning techniques (Nguimbi et al., 2014). Al Farraj et al. enhanced the production of fibrinolytic enzyme from a new bacterium Bacillus flexus obtained from marine environments by using statistical approach, two-level full factorial design $2^{5}$ and response surface methodology, to optimize the conditions for the production of fibrinolytic enzyme using solid state fermentation process. Under this optimized condition, they improved the fibrinolytic enzyme output up to 3.5 fold (Al Farraj et al., 2020). Submerged fermentation has also been chosen for the discovery of fibrinolytic enzyme and for improving the production efficacy. Anusree et al. optimized the production of fibrinolytic enzyme isolated from Serratia rubidaea KUAS001 by using submerged fermentation (Anusree et al., 2020). Staphylokinase (SAK) from Staphylococcus aureus GH38 was also screened by using submerged fermentation (Noori and Aziz, 2020); while Pan et al. reported for the first time the use of non-sterile submerged-fermentation to reduce the production cost of fibrinolytic enzyme from Bacillus subtilis D21-8 (Pan et al., 2019a). Furthermore, use of different statistical tools such as Box-Benhken design (Kumar et al., 2018), two-level full factorial design $\left(2^{5}\right)$ (Vijayaraghavan et al., 2016a; Vijayaraghavan et al., 2016b), response surface methodology (RSM), central composite 
TABLE 1 | Fibrinolytic enzymes produced by bacteria from different sources.

Bacteria

Bacillus flexus

Pseudomonas aeruginosa KU1

Serratia rubidaea

Staphylococcus aureus GH38

Fictibacillus sp. strain SKA27

Bacillus subtilis WR350

Bacillus subtilis D21-8

Bacillus cereus RSA1

Alcaligenes aquatilis PJS_1

Bacillus pseudomycoides strain MA02

Pseudomonas aeruginosa KU1

Stenotrophomonas sp. KG-16-3

Stenotrophomonas maltophilia Gd2

Bacillus tequilensis

Bacillus subtilis

Serratia marcescens subsp. sakuensis

Serratia sp KG-2-1

Bacillus cereus SRM-001

Bacillus subtilis

Actinomycete

Streptomyces sp

Bacillus Amyloliquefaciens UFPEDA 485

N.A.

Bacillus sp. IND12

Shewanella sp. IND20

Bacillus cereus SRM-001

Proteus penneri SP-20

Bacillus licheniformis

Streptomyces sp. P3

Brevibacillus brevis strain FF02B

Streptomyces sp. DPUA 1576

Pseudoalteromonas sp. IND11

Bacillus subtilis I-2

Bacillus sp. UFPEDA 485

Bacillus subtilis GXA-28

Bacillus subtilis HQS-3

Bacillus cereus NS-2

Bacillus cereus GD 55

B. cereus, B. circulans, $P$. aeruginosa, $P$.

fluorescens, E.coli

Streptomyces sp. XZNUM 00004

Streptomyces venezuelae

B. subtilis, streptococci,

Pseudomonas sp

Bacillus subtilis TKU007

Streptomyces sp. CS624

Paenibacillus polymyxa EJS-3

Bacillus sp. strain AS-S20-

Source

Name of enzyme

eferences

South West coast of India

Marine sediments of Ezhara beach

Marine samples (sediments, water)

From a patient suffering from burns

Sand, seashells, and marine water

Through UV mutagenesis of $B$. subtilis HQS-3

Through UV mutagenesis of $B$. subtilis HQS-3

From soil

Soil from slaughter houses

From poultry slaughter house soils

From marine sediments

Soil samples from different habitats (dairy, garbage

dump, slaughter house)

From soil

From soil

From Egyptian soil

Sea water

Garbage dump soil sample

Blood-laden soil of a chicken waste-dump yard

N.A.

From Microbial Biotechnology Research Laboratory

(MBRL) culture collection

Amazonian lichens

Cultures Collections of Department of Antibiotics

Sea water

Soil, fish, and rice

From fish Sardinella longiceps

Blood-laden soil of a chicken dump yard

Soil from slaughter house waste

Soil samples from hot Spring

From air-dried soils

N.A.

Amazon lichens

Fish scales

Soil from slaughter-houses, dairy, domestic garbage and compost

Collection of Microorganisms

China Center for Type Culture Collection

Marine sample

From slaughter houses, dairy and domestic garbage)

From soils

From slaughter houses of beef, chicken and fish

From rhizosphere soil of $P$. sibiricum

From marine water

From soil sample, blood and biomass from infected

throat, human urine respectively

From soil

From soil

From tissues of Stemona japonica
N.A.

Pseudomonas aeruginosa KU1 (PEKU1)

Serratia rubidaea KUAS001

Staphylokinase (SAK)

N.A.

N.A.

N.A.

Protease

N.A.

Protease

N.A.

Protease

Protease

N.A.

N.A.

N.A.

Protease

N.A.

Bacillopeptidase CFR5 (BPC)

N.A.

Serine protease

Serine-metalloprotease

Metalloprotease

N.A.

N.A.

N.A.

Protease

Protease

FSP3: serine protease

Brevithrombolase: serine protease

N.A.

N.A.

Protease

Metalloprotease

N.A.

Serine metalloprotease

Protease

Protease

Protease

Streptomyces fibrinolytic enzyme-1 (SFE1)

Thrombinase

Nattokinase, Streptokinase and

Urokinase

Bacillus subtilis nattokinase-1 BSN1

FES624: chymotrypsin-like serine metalloprotease

Paenibacillus polymyxa EJS-3

fibrinolytic enzyme-1 (PPFE-I)

Bafibrinase: Serine protease
Al Farraj et al. (2020)

Kumar et al. (2020)

Anusree et al. (2020)

Noori and Aziz (2020)

Joji et al. (2019)

Wu et al. (2019)

Pan et al. (2019a), Pan et al.

(2019b)

Sharma et al. (2020)

Prabhu et al. (2020)

Chandramohan et al. (2019)

Kumar et al. (2018)

Taneja et al. (2019)

Khursade et al. (2019)

Xin et al. (2018)

Moharam et al. (2019)

Krishnamurthy et al. (2017)

Taneja et al. (2017)

Narasimhan et al. (2018)

Sharmila and Venkateswaran (2017)

Ningthoujam and Thokchom

(2016)

Silva et al. (2016)

de Souza et al. (2016)

Velumani, (2016)

Vijayaraghavan et al. (2017)

Vijayaraghavan and Prakash

Vincent (2015)

Narasimhan et al. (2015)

Jhample et al. (2015)

Shukor et al. (2015)

Cheng et al. (2015)

Majumdar et al. (2015)

Silva et al. (2015)

Vijayaraghavan and Vincent

(2014)

Bajaj et al. (2014)

Sales et al. (2013)

Zeng et al. (2013)

Huang et al. (2013)

Bajaj et al. (2013)

Raju and Divakar (2013a)

Raju and Divakar (2013b)

Ju et al. (2012)

Naveena et al. (2012)

Dubey et al. (2011)

Wang et al. (2011)

Mander et al. (2011)

Lu et al. (2010)

Mukherjee et al. (2012)

N.A., not available. 
TABLE 2 | Fibrinolytic enzymes produced by algae from different sources.

\begin{tabular}{|c|c|c|c|}
\hline Algae & Source & Name of enzyme & References \\
\hline Arthrospira platensis & Culture collection of Algae & Serine metalloprotease & de Barros et al. (2020) \\
\hline Chlorella vulgaris UTEX 1803 & From University of Texas, Austin & Protease & Silva et al. (2018) \\
\hline Chlorella Vulgaris & University of Texas, Austin & Protease & Páblo et al. (2017) \\
\hline Undaria pinnatifida & Sigma (St. Louis, MO, United States) & Tissue-type plasminogen activator & Min et al. (2016) \\
\hline Ulva pertusa & Coastal area & Ulvease: serine protease & Kang et al. (2016) \\
\hline Lyophyllum shimeji & Yedang Mushroom Co & a chymotrypsin like serine metalloprotease & Moon et al. (2014) \\
\hline Costaria costata & Coastal area & Serine protease & Kim et al. (2013) \\
\hline Codium fragile & Coastal area & Codiase: serine protease & Choi et al. (2013) \\
\hline
\end{tabular}

TABLE 3 | Fibrinolytic enzymes obtained from fungi from different sources.

\begin{tabular}{|c|c|c|c|}
\hline Fungi & Source & Name of enzyme & References \\
\hline Mucor subtilissimus UCP 1262 & N.A. & Protease & da Silva et al. (2019) \\
\hline Cordyceps militaris & N.A. & Serine protease & Liu et al. (2017) \\
\hline Xylaria curta & Stem of plant: Catharanthus roseus & Protease & $\begin{array}{l}\text { Kim et al. (2011); Meshram } \\
\text { et al. (2017) }\end{array}$ \\
\hline Mucor subtillissimus UCP 1262 & Soil & Protease & Nascimento et al. (2015) \\
\hline Aspergillus japonicum KSS 05 & Soil & N.A. & Shukor et al. (2015) \\
\hline Pleurotus ostreatus & Microbiological Culture collection Center & Metallo-endopeptidases & Liu et al. (2014) \\
\hline Coprinus comatus YY-20 & N.A. & N.A. & Liu et al. (2012) \\
\hline Cordyceps militaris & N.A. & Chymotrypsin-like serine metalloprotease & Choi et al. (2011) \\
\hline Mucor subtilissimus UCP 1262 & Soil & Protease & Nascimento et al. (2016) \\
\hline Xylaria curta & Cathranthus roseus twigs & Xylarinase: metalloprotease & Meshram et al. (2016) \\
\hline Endophytic Fungi & Hibiscus leaves & Protease & Ahmad et al. (2014) \\
\hline $\begin{array}{l}\text { Trichoderma, Aspergillus, Penicillium, } \\
\text { Rhizopus and Mucor }\end{array}$ & Alkaline soil & Protease & Palanivel et al. (2013) \\
\hline Aspergillus brasiliensis AUMC 9735 & $\begin{array}{l}\text { Dairy products, meats, soybean powders, } \\
\text { soil and water samples }\end{array}$ & Metalloprotease & Kotb et al. (2015) \\
\hline Paecilomyces tenuipes & $\begin{array}{l}\text { Culture collection of DNA Bank of } \\
\text { Mushrooms }\end{array}$ & $\begin{array}{l}\text { Paecilomyces tenuipes entomopathogenic } \\
\text { fibrinolytic protease: PTEFP }\end{array}$ & Kim et al. (2011) \\
\hline Bionectria sp. & Las Yungas rainforest & Serine-proteases & Rovati et al. (2009) \\
\hline
\end{tabular}

N.A., not available.

design (CCD) and artificial neural network (ANN) (Chandramohan, et al., 2019; Joji et al., 2019), as well as orthogonal experiment ( $\mathrm{Wu}$ et al., 2019) have been reported to optimize the concentration of media components used for fermentation to obtain fibrinolytic enzymes in order to enhance their production yield.

Besides optimizing the fermentation condition, gene cloning, mutagenesis and DNA recombination technology have also been used to enhance fibrinolytic enzyme production. Using gene cloning, Yao et al. obtained a recombinant fibrinolytic enzyme with significantly higher fibrinolytic activity, rAprEBS15, isolated from Bacillus pumilus BS15 (Yao et al., 2018). Using codon optimization, gene dosage and process optimization, Che et al. expressed and secreted fibase, a fibrinolytic enzyme from marine Bacillus subtilis, and significantly enhanced its activity (Che et al., 2020).

Other microorganisms such as algae, fungi, and fermented foods have also been used to obtain fibrinolytic enzymes by either using different fermentation methods or aqueous two phase systems (Nascimento et al., 2016; Meshram et al., 2017). Algae are sources for fibrinolytic enzymes that belong to proteases, metalloproteases, and tissue-type plasminogen activator (Choi et al., 2013; Kim et al., 2013; Moon et al., 2014; Kang et al., 2016;
Min et al., 2016; e et al., 2017; Silva et al., 2018; de Barros et al., 2020) (Table 2); while fungi are important sources for fibrinolytic enzymes that belong to proteases, metalloproteases and metalloendopeptidase (Rovati et al., 2009; Choi et al., 2011; Kim et al., 2011; Liu et al., 2012; Palanivel et al., 2013; Ahmad et al., 2014; Liu et al., 2014; Kotb et al., 2015; Shukor et al., 2015; Meshram et al., 2016; Nascimento et al., 2016; Meshram et al., 2017; Liu et al., 2017; da Silva et al., 2019) (Table 3).

Fermented foods are also known as sources for fibrinolytic enzymes (Table 4). Fermented soybeans have been consumed as traditional foods in many Asian countries, and indeed, they are sources of nattokinase and other fibrinolytic enzymes. These includes natto, a Japanese traditional fermented soybean obtained from fermentation with Bacillus subtilis G8 and Bacillus subtilis (Chang et al., 2012; Lucy et al., 2019), moromi, oncom and gambus (Indonesian traditional fermented soybean obtained from fermentation with Bacillus cereus, Bacillus subtilus, Bacillus pumilus, and Stenotrophomonas sp, respectively) (Afifah et al., 2014; Nailufar et al., 2016; Stephani et al., 2017; Syahbanu et al., 2020) as well as douchi and doufuru (Chinese traditional fermented soybean obtained from fermentation with Bacillus 
TABLE 4 | Fibrinolytic enzymes from microorganisms food products.

\section{Microorganisms}

Bacillus cereus, B. subtilis, B. cereus.

Bacillus-Genus

N.A.

N.A.

Bacillus subtilis DC27

Bacillus subtilis G8

Bacillus. velezensis BS2

Xanthomonas oryzae IND3

Bacillus pumilus BS15

Stenotrophomonas sp

Stenotrophomonas $\mathrm{sp}$

Bacillus amyloliquefaciens

Fungus (Neurospora sitophila)

Bacillus sp. IND7

Bacillus cereus IND5

Bacillus halodurans IND18

Bacillus subtilis XZ1125

N.A.

Bacillus sp

Lactococcus lactis, Vagococcus lutrae, V. fluvialis, Weissella

thailandensis, B methylotrophicus

Bacillus pumilus

Bacillus amyloliquefaciens, Bacillus licheniformis

Bacillus coagulans

Bacillus amyloliquefaciens CB1

Bacillus subtilis FR-33

Virgibacillus sp. SK37

Bacillus subtilis WRL 101

Bacillus subtilis

Bacillus subtilis LD-8547

Aspergillus oryzae KSK-3

Bacillus amyloliquefaciens MJ5-41

Bacillus amyloliquefaciens

Bacillus subtilis DC33

Bacillus sp

\begin{tabular}{ll}
\multicolumn{1}{c}{ Name of enzyme } & \multicolumn{1}{c}{ Food } \\
$\begin{array}{l}\text { Protease } \\
\text { N.A. }\end{array}$ & $\begin{array}{l}\text { Indonesian fermented soybean: moromi } \\
\text { Brazzaville: Squash }\end{array}$ \\
N.A. & Japanese fermented food: funazushi \\
JP-I (Jotgal protease-I) and JP-II & Korean traditional fermented food: Jotgal \\
Douchi fibrinolytic enzyme: & Chinese fermented soybean food: Douchi \\
DFE27 & \\
N.A. & Japanese Fermented Natto Soybeans \\
N.A. & Korean fermented seafood: sea squirt \\
& (munggae) jeotgal \\
Protease & Fermented rice
\end{tabular}

N.A.

Extracellular protease

N.A.

N.A.

N.A.

Protease

N.A.

N.A.

N.A.

N.A.

N.A.

N.A.

N.A.

Nattokinase

N.A.

AprECB1

N.A.

Proteinase

Nattokinase WRL101

Subtilisin-like serine protease

Douchi fibrinolytic enzyme (DFE)

Serine protease

AprE5-41

N.A.

Subtilisin-like serine protease:

subtilisin FS33

N.A.
References

Syahbanu et al. (2020)

SolokaMabika et al.

(2020)

Ito (2020)

Kim et al. (2020)

Hu et al. (2019)

Lucy et al. (2019)

Yao et al. (2019)

Vijayaraghavan et al. (2019)

Yao et al. (2018)

Stephani et al. (2017)

Nailufar et al. (2016)

Huy et al. (2016)

Liu et al. (2016)

Vijayaraghavan et al.

(2016a)

Biji et al. (2016)

Vijayaraghavan et al.

(2016b)

Bi et al. (2015)

Johnson et al. (2015)

Anh et al. (2015)

Indonesian palm wine: tuak

Fermented Shrimp Paste

Fermented soybean foods of North-East

India

Indonesian fermented soybean cake:

gembus

Spoilt milk and soy flour

Indonesian fermented fish products:

Terasi and Jambal roti

Korean fermented soy food:

cheonggukjang

Chinese soy cheese doufuru

Brewery Yeast Sludge

\section{Doenjang}

Fermented natto-red bean

Chinese soybean-fermented food: Douchi

Rice koji

Korean fermented soy product: Meju

Chinese soybean paste

Chinese soybean-fermented food: Ba-

bao Douchi

Korean fermented soybean paste
Thokchom and Joshi (2014)

Afifah et al. (2014)

Gad et al. (2014)

Prihanto and Firdaus,

(2019)

Heo et al. (2013)

Chen et al. (2013)

Lapsongphon et al.

(2013)

Park et al. (2013)

Chang et al. (2012)

Yuan et al. (2012)

Shirasaka et al. (2012)

Jo et al. (2011)

Wei et al. (2011)

Wang et al. (2006)

Ok and Choi (2005)

N.A., not available.

subtilis DC27, Bacillus subtilis LD-8547, Bacillus subtilis DC33, and Bacillus subtilis FR-33) (Ok and Choi, 2005; Wang et al., 2006; Jo et al., 2011; Wei et al., 2011; Yuan et al., 2012; Chen et al., 2013; Heo et al., 2013; Park et al., 2013; Gad et al., 2014; Thokchom and Joshi, 2014; Bi et al., 2015; Huy et al., 2016; Liu et al., 2016; Nailufar et al., 2016; Hu et al., 2019; Ito, 2020; Syahbanu et al., 2020). Moreover, fibrinolytic enzymes could also be obtained from other fermented products, such as rice fermented with Xanthomonas oryzae IND3, Bacillus cereus IND5, Bacillus halodurans IND18, Bacillus sp. IND7 and Aspergillus oryzae KSK-3 (Shirasaka et al., 2012; Biji et al., 2016; Vijayaraghavan et al., 2016a; Vijayaraghavan et al., 2016b; Vijayaraghavan et al., 2019), seafood fermented with
Bacillus sp, Bacillus. velezensis BS2, Bacillus pumilus BS15 and Bacillus coagulans (Anh et al., 2015; Prihanto and Firdaus, 2019; Yao et al., 2019; Kim et al., 2020) and liquors obtained from fermentation with Bacillus amyloliquefaciens, Bacillus licheniformis and Bacillus-Genus (Lapsongphon et al., 2013; Johnson et al., 2015; SolokaMabika et al., 2020).

\section{MACRO-ORGANISMS AS SOURCES OF FIBRINOLYTIC ENZYMES}

While microorganisms are the main sources for fibrinolytic enzymes, they have also been isolated from non-microbial 
TABLE 5 | Fibrinolytic enzymes produced by plants.

Plant

Gliricidia sepium PBSGS

Ficus carica

Petasites japonicus

Cnidoscolus urens (L.)

Aster yomena

Artocarpus heterophyllus

Euphorbia hirta

Chive (Allium tuberosum)

Chive (Allium tuberosum)

\section{Name of enzyme}

Cysteine protease

Serine protease

Serine protease

Acid protease

Kitamase: Protease

Serine protease

Hirtin: serine protease

Allium tuberosum fibrinolytic enzyme (ATFE): Serine protease

ATFE-II: Serine protease
References

da Silva et al. (2020)

Hamed et al. (2020)

Kim et al. (2015)

De Menezes et al. (2014)

Choi et al. (2014)

Siritapetawee et al. (2012)

Patel et al. (2012)

Chung et al. (2010b)

Chung et al. (2010b)

TABLE 6 | Fibrinolytic enzymes obtained from non-microbial sources.

\section{Organism}

Parasite (Rhipicephalus microplus)

Sponge (Agelas conifer)

Earthworm (Pheretima posthumous)

Earthworm (Lumbricus rubellus)

Earthworm Eisenia fetida

Bothrops colombiensis venom

Trimeresurus mucrosquamatus venom

Bathroxobin atrox snake venom

\section{Name of enzyme}

BmCL1 (Rhipicephalus [Boophilus] microplus Cathepsin-L like 1); a protease

Protease from Streptomyces radiopugnans VITSD8

Serine protease

Lumbrokinase

Lumbrokinases (protease)

Colombienases: metalloproteinase

TM-1

Batroxase: metalloproteinase
References

Xavier et al. (2019)

Dhamodharan et al. (2019)

Verma and Pulicherla (2017)

Fu et al. (2016)

Fu et al. (2013)

Girón et al. (2013)

Chou et al. (2013)

Cintra et al. (2012) organisms such as plants, parasites, snake venoms and earthworms. Plants are also important sources of fibrinolytic enzymes, especially proteases (Table 5). Cysteine protease could be extracted from the leguminous Gliricidia sepium PBSGS using aqueous two-phase systems of sodium phosphate and PEG (da Silva et al., 2020); while serine proteases, which have the potential to degrade $\alpha, \beta$ and $\gamma$ chains of fibrinogen and fibrin clots, could be extracted from different plants, including latex of Ficus carica, leaves of Cnidoscolus urens (L.), leaves of Petasites japonicas, latex of Artocarpus heterophyllus, leaves of Aster yomena, leaves of Allium tuberosum and latex of Euphorbia hirta (Chung et al., 2010a; Chung et al., 2010b; Patel et al., 2012; Siritapetawee et al., 2012; Choi et al., 2014; De Menezes et al., 2014; Kim et al., 2015; Hamed et al., 2020).

Other sources of fibrinolytic enzymes include snake venoms, earthworms, sponge, and parasites (Cintra et al., 2012; Chou et al., 2013; Fu et al., 2013; Girón et al., 2013; Fu et al., 2016; Verma and Pulicherla, 2017; Dhamodharan et al., 2019; Xavier et al., 2019). Snake venoms contain metalloproteases, which are fibrinolytic enzymes consists of a group of multigene protein families involved in many activities of fibrinolysis, hemorrhage, apoptosis, anti-coagulant antiplatelet and pro-coagulant effects (Sanchez et al., 2017). Metalloproteases could be obtained from the venoms of Bothrops colombiensis, Trimeresurus mucrosquamatus, and Bathroxobin atrox (Table 6). Snake venom metalloproteinases (SVMPs) are classified into four groups (PI to PIV) based on their domain structures. PI group snake venom metalloproteinases have molecular masses ranging from 20 to $30 \mathrm{kDa}$, contain only proteinase domain and have a weak hemorrhagic activity (Fox and Serrano, 2009). PII group contains both proteinase and disintegrin-like domains containing $30-60 \mathrm{kDa}$ proteins. PIII group proteins comprised of a cysteine- rich domain, while PIV proteins include an additional lectin-like domain (Fox and Serrano, 2005). Snake venom metalloproteinases (SVMPs) are involved in fibrinolysis, in activating coagulation process through proteolytic activity, and in activating coagulation factors such as factor X and II. Furthermore, they are involved in inhibition or induction of platelet aggregation (Cintra et al., 2012). Besides serine proteases, earthworms such as Lumbricus rubellus and Eisenia fetida could produce lumbrokinase, a fibrin specific protease which could lower blood viscosity, minimizing platelet accumulation and promote thrombus dissolution by transporting them into the blood via intestinal epithelium (Fu et al., 2013; Verma and Pulicherla, 2017). Lumbrokinase exists as a complex of six serine protease isoforms, each isoform has different molecular weights ranging from 14 to $33 \mathrm{kDa}$ with variety in fibrinolytic activity (Verma and Pulicherla, 2017). It has dual mechanism in clot degradation: acts on fibrin directly and activates plasminogen and convert it into plasmin, which subsequently induce plasmin-based clot dissolution (Wang et al., 2004). Another example of fibrinolytic enzyme from non-microbial organism is Rhipicephalus (Boophilus) microplus Cathepsin-L like 1 (BmCL1), which is isolated from Rhipicephalus microplus, a parasite grows on cattle and other animals. BmCL1 comprised of two isoforms with molecular weights of 26 and $22 \mathrm{kDa}$. It could degrade fibrinogen by hydrolyzing $\mathrm{A} \alpha$ - and $\mathrm{B} \beta$-chains (Xavier et al., 2019).

\section{FIBRINOLYTIC ENZYMES AS DRUGS FOR TREATING THROMBIN}

\section{Streptokinase}

Among the plasminogen activators, streptokinase (streptokinase) is the first drug approved by FDA for thrombosis treatment since 

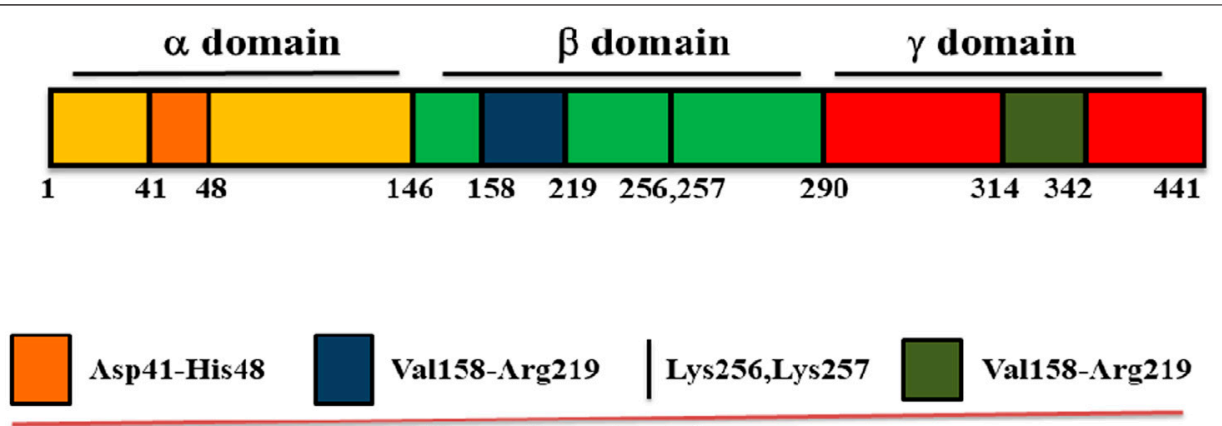

Functional regions

FIGURE 1 |Domain structure of streptokinase. Streptokinase consists of three domains: $\alpha$ domain at 1-146, $\beta$ domain at 147-290, and $\gamma$ domain at 291-414 of the amino acid positions. It also contains many functional regions across the domain such as Asp41-His48 region between the first to 59 th 59 amino acid residues of a domain, Lys256, Lys257, and Val158-Arg219 region of $\beta$ domain, as well as Leu314-Ala342 region of $\gamma$ domain.

1950s. Streptokinase is a bacterial protein obtained from $\beta$-hemolytic streptococci of Lancefied groups A, C and G (Roohvand, 2018). The group C strain of Streptococcus equisimilis H46A (ATCC 12449 and ATCC 9542, introduced for streptokinase production in 1945 and 1992, respectively) have been widely used for production of streptokinase (Vadla et al., 2019). At present, streptokinase is available commercially under the trade names of Indikinase, Kabikinase, Varidase and Streptase (Roohvand, 2018).

Streptokinase is a single polypeptide enzyme made up of 414 amino acid residues with molecular weight of $47 \mathrm{kDa}$ and performs its maximum activity at $\mathrm{pH}$ 7.5. It converts inactive plasminogen to plasmin through a series of protein-protein interactions that comes to an end with the formation of streptokinase-plasmin complex (Kazemi et al., 2019). Streptokinase does not contain cysteine, lipids, phosphorous and conjugated carbohydrates, and is made up from three structural domains: $\alpha$ domain at 1-146, $\beta$ domain at 147-290 and $\gamma$ domain at 291-414 amino acid positions linked by two flexible coil regions (Figure 1). There are many exosites or functional regions across the domains of streptokinase, including the Asp41-His48 region between 1-59 amino acid residues of a domain which controls its binding to plasminogen and activation (Sazonova et al., 2004; Verhamme and Bock, 2014), a 250 loop along with the pair of Lys 256, Lys 257 and Val158-Arg219 region of $\beta$ domain which is responsible for plasminogen recognition, processing and streptokinaseplasmin complex formation (Tharp et al., 2009), and a coiled region of streptokinase $\gamma$ domain (Leu314-Ala342) which regulates streptokinase-micro plasmin complex stabilization for plasminogen activation. Along with functional groups and exosites, streptokinase also contains hot spots or single residues for substitutions, such as V19F, V35E and S44K in its a domain, which play important role for the activation of streptokinase-plasmin complex (Aneja et al., 2013; Kazemi, et al., 2019).

Being a microbial protein, streptokinase is immunogenic and could trigger immune response. This limits its therapeutic potential, as it cannot be re-administered after its first use. Furthermore, its half-life in the blood flow is short. To overcome these limitations, studies have been made by using various strategies, including the structural modifications, chemical modifications, liposomal entrapment or encapsulation, and domain fusion (Roohvand, 2018). Structural modifications have been done using deletions, or substitutions of the amino acids. For example, two truncated streptokinase proteins (SK60-386 and SK143-386) showed enhanced fibrin-specific activity and lower immunogenicity compared to the full length streptokinase (Arabi et al., 2011); while substitution of Lys59 and/or Lys386 for glutamine increased its half-life (Adivitiya et al., 2018). Chemical modifications have been done by site specific or homogenous PEGylation or acylation (anisoylated plasminogen-streptokinase activator complex; APSAC) (Kunadian and Gibson, 2012). For instance, cysteine-specific thiol-mediated PEGylation of streptokinase increased its stability and half-life (Sawhney et al., 2016); while acylation of a complex consisting of human plasminogen and bacterial streptokinase (anisoylated plasminogen-streptokinase activator complex; APSAC) enhanced its specificity for blood clot (Ali et al., 2014). Modification in the delivery system of streptokinase, for example using liposomal entrapment or encapsulation of streptokinase in PEG or chitosan nanoparticles as well as platelet directed liposomes have also been explored (Vaidya et al., 2011; Baharifar et al., 2020; Hasanpour et al., 2021). These modifications not only could enhance its stability and half-life, but also could reduce its immunogenicity and improves its clot penetration properties. Another effort for improving streptokinase is domain fusion to produce chimeric and conjugated streptokinase proteins. Maheshwari et al. found that fusion of streptokinase with epidermal growth factor 4, 5, and 6 domains of human thrombomodulin reduced the risk of reocclusion and hemorrhage (Maheshwari et al., 2016). Together, these modifications improve both the activity and drug ability of streptokinase, while reducing its side-effects.

\section{Staphylokinase}

Staphylokinase is a bacterial protein that exerts its anti-thrombin activity by converting inactive plasminogen into active plasmin. It is found in the culture medium of many strains of Staphylococcus 


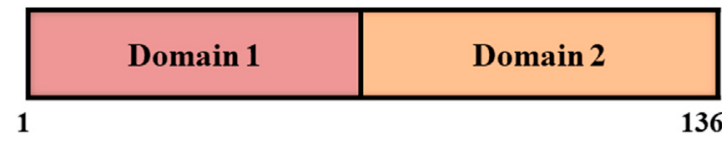

FIGURE 2|Domain structure of staphylokinase consisting two domains of equal size.

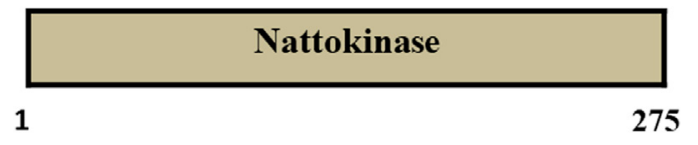

FIGURE 3 | Domain structure of nattokinase consisting of a single polypeptide chain. aureus (Gerheim, 1948; Lack, 1948). Initially, Davidson and Glanville precipitated protein containing staphylokinase by adjusting the $\mathrm{pH}$ to 3.3 with $\sim 10 \mathrm{mM} \mathrm{HCl}$ from supernatant fluid of cultures (Davidson, 1960; Glanville, 1963). SAK is a single polypeptide chain of 136 amino acids with molecular weight of 15.5 KDa, which has two domains of equal size with flexible dumbbell shape (Figure 2) (Bokarewa et al., 2006; Nedaeinia et al., 2020).

Staphylokinase does not directly degrade the fibrin. Indeed, it performs its activity in two- step mechanism. Firstly, a complex is formed between staphylokinase and plasminogen, then the active site of this complex is accessible to transform plasminogen into plasmin. After the formation of this complex, a peptide bond between lysine 10 and 11 of staphylokinase is hydrolyzed, and this in turn triggers the lysis of peptide bond between arginine 561 and valine 562 of plasminogen (Pulicherla et al., 2013). This results in the initial conversion of plasminogen to plasmin in staphylokinase-plasminogen complex. After small amount of plasmin has been synthesized, staphylokinase binds to plasmin, and finally this complex promptly and directly converts plasminogen to plasmin. The formation of these complexes, either to plasmin or plasminogen, is hampered by a2-antiplasmin in the absence of fibrin (Lijnen et al., 1992; Ram et al., 2013; Nedaeinia, et al., 2020). Thus, staphylokinase is fibrin specific and give good response to clot degradation and can be used potentially for the removal and treatment of blood clots (Nedaeinia, et al., 2020); however, its short half-life rendered its clinical use, and efforts are necessary to overcome this problem (Akhtar et al., 2017).

\section{Nattokinase}

Nattokinase is a serine protease produced from the traditional Japanese food natto through the process of fermentation of soybeans with the bacterium Bacillus subtilis, and extracted for the first time by Sumi et al. in 1980s (Sumi et al., 1987; Nagata et al., 2017). It has a single polypeptide chain comprises of 275 amino acids with molecular mass of $27.7 \mathrm{KDa}$ (Figure 3), and can work at the $\mathrm{pH}$ of $6-12$ and temperature up to $60^{\circ} \mathrm{C}$ (Maeda et al., 2001).

Nattokinase increases the natural ability of the body to degrade the blood clots in different ways and confer many advantages such as oral administration, efficacy, cost effective, long lasting effects, stability in the gastrointestinal tract, as well as its potential to increase the ability of body to produce plasmin and urokinase (Kotb, 2012). It works by directly degrading the fibrin and plasmin substrate, transforms pro-urokinase into uPA, hydrolyses PAI-1 and enhance the level of tPA, which facilitate fibrinolytic activity (Sumi, et al., 1987; Yatagai et al., 2007; Chen et al., 2018). Furthermore, both in vivo and in vitro toxicology experiments have provided strong evidence about the safety of nattokinase for human oral consumption, as until now, there is no toxicity detected upon its usage (Lampe and English, 2016). Thus, nattokinase is a potential enzyme for dissolving blood clot, and has been extensively studied in Korea, Japan and China (Weng et al., 2017). Furthermore, its clinical trials for atherothrombotic prevention are being held in United States (Weng et al., 2017).

\section{Urokinase-Type Plasminogen Activator}

Urokinase plasminogen activator, which is also known as urokinase, was first identified in 1947 in urine as unnamed novel fibrinolytic protein by MacFarlane and Pilling (1947) before being named as urokinase half a decade later (MacFarlane and Pilling, 1947; Sobel et al., 1952). It is produced and secreted as an inactive single polypeptide chain of 411 amino acids called pro-urokinase or pro-uPA from macrophages, endothelial cells, some tumor cells, and renal epithelial cells. Urokinase is comprised of three domains: growth factor domain (GFD, from 1 to 49 amino acids in the pro$\mathrm{uPA}$ protein) and kringle domain (KD, from 50 to 131 amino acids) which are both located at the $\mathrm{N}$ - terminus, as well as a serine protease domain (P, from 159 to 411 amino acids) at the C-terminus of the pro-uPA protein. The N-terminal and C-terminal regions of prouPA are linked by a linker region (from 132 to 158 amino acids). After being secreted, pro-uPA goes through a two-rounded proteolytic process that cleaves it between Lys158 and IIe159 at the linker region; however, the two chains formed are still linked through disulfide bond. Two chains uPA has a molecular weight of $54 \mathrm{kDa}$. A second round cleavage at the peptide bond between Lys135 and Lys 136 totally cleaves the two chain of uPA into two parts: the inactive amino-terminal fragment (ATF) that contains growth factor domain and kringle domain, and a low molecular weight $(33 \mathrm{kDa})$ active form of uPA with serine protease domain (Figure 4) (Poliakov et al., 2001). Finally, due the presence of GFD and amino-terminal fragment (ATF), pro-uPA as well as the two chain forms of uPA (active serine protease domain and inactive ATF with growth factor domain and kringle domain) binds to its receptor (uPAR) with similar affinity. This binding in turn enhances the conversion of plasminogen into plasmin (Blasi and Carmeliet, 2002; Mahmood et al., 2018; Kadir and Bayraktutan, 2020). Owing to its high activity as a plasminogen activator, urokinase is a potential drug approved by FDA for clinical use for the treatment of cardiovascular diseases (Akhtar et al., 2017).

\section{Recombinant Tissue-Type Plasminogen Activator}

Tissue plasminogen activator is a serine protease with fibrin specific thrombolytic activity. It has a molecular weight of 

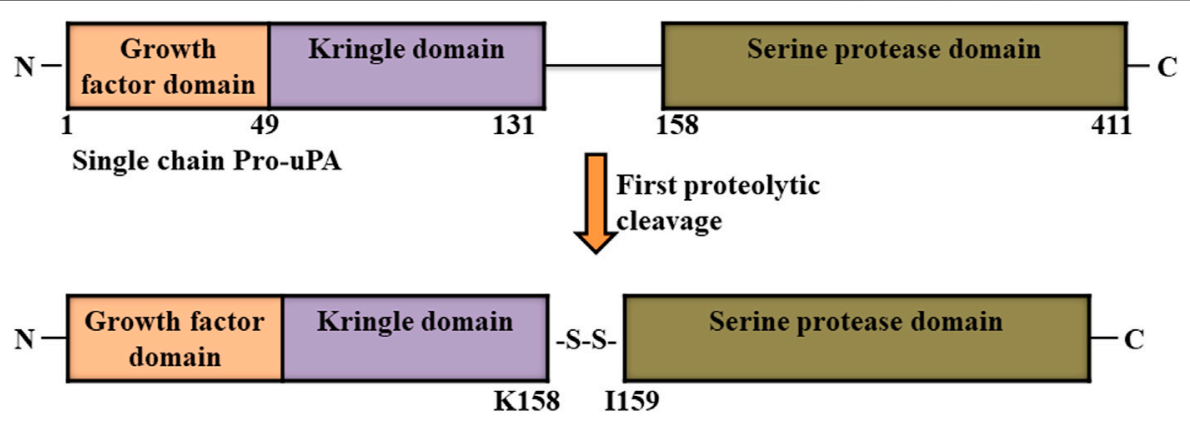

Two chains active uPA

Second proteolytic

cleavage

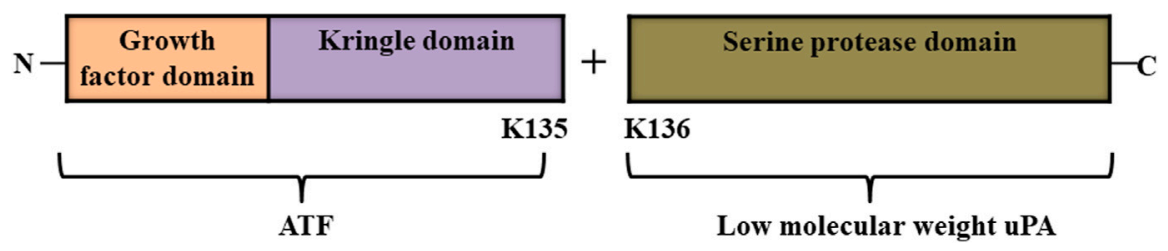

FIGURE 4 | Structure of urokinase-type plasminogen activator (UPA). Pro-uPA is secreted as an inactive single polypeptide chain consisting of a growth factor domain, kringle domain and serine protease domain, and undergoes first proteolytic cleavage between its Lys158 and lle159. A second-round cleavage at the peptide bond between its Lys 135 and Lys 136 totally cleaves the two chains of uPA into two parts: the inactive amino-terminal fragment (ATF) and active low molecular weight form of uPA (Mahmood et al., 2018).

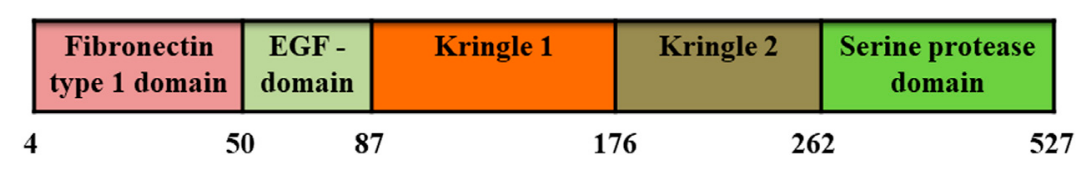

FIGURE 5 |Domain structure of recombinant tissue-type plasminogen activator (rtPA). It consists of fibronectin type I domain, an epidermal growth factor domain, as well as kringle 1, kringle 2 and serine protease domains.

$70 \mathrm{kDa}$ and consisting of 527 amino acids. It comprises of five domains: i) a fibronectin type I domain at N-terminal with 47 amino acid residues (F, 4-50 residues), ii) an epidermal growth factor domain (EGF, residue 50-87), iii) kringle 1 (K1, 87 to 176 residues), iv) kringle 2 (K2, 176-262 residues), and v) a serine protease domain (P, residues 276-527) (Figure 5) (Lee and Im, 2010; Nedaeinia, et al., 2020). The activity of plasminogen activator is weak in the absence of fibrin; while the presence of fibrin significantly increased its activity. Furthermore, its activity is inhibited in vivo by PAI- 1 and the amino acids at 296-299 are crucial for this inhibition (Ram et al., 2013). To overcome such drawbacks, different forms of recombinant tPA, including Alteplase, Reteplase, Tenecteplase, and Desmoteplase have been developed using recombinant DNA technology. Among them, Tenecteplase and Reteplase are approved for clinical use (Wander and Chhabra, 2013); however, they still have side effects of bleeding complications, fibrin specificity and allergic reactions (Ram et al., 2013). Therefore, currently, many researchers are focusing on reducing these side effects and increasing efficacy of these fibrinolytic enzymes. For example, magnetic nanoparticles-based dual targeted delivery strategy (peptide/rtPA conjugated poly(lactic-co-glycolic acid) (PLGA) magnetic nanoparticles (PMNPs)) increased the fibrin specificity of rtPA (Ram et al., 2013; Chen et al., 2020; Nedaeinia, et al., 2020); while Güner et al. used the strategy of prolonged thrombolytic therapy with low-dose and slow-infusion of tissue-type plasminogen activator. This strategy reduced the bleeding complications to a significant level (Güner et al., 2020). Taken together, if the above mentioned side effects are controlled, rtPAs could be promising drugs for thrombolytic therapy.

\section{DISCUSSION}

Since its discovery, various fibrinolytic enzymes have been discovered from different sources, and have been used for the thrombolytic therapy (Figure 6; Table 7). They are reducing the risk of morbidity and mortality rates related to stroke, myocardial infarction and cardiovascular diseases. Various kinds of 


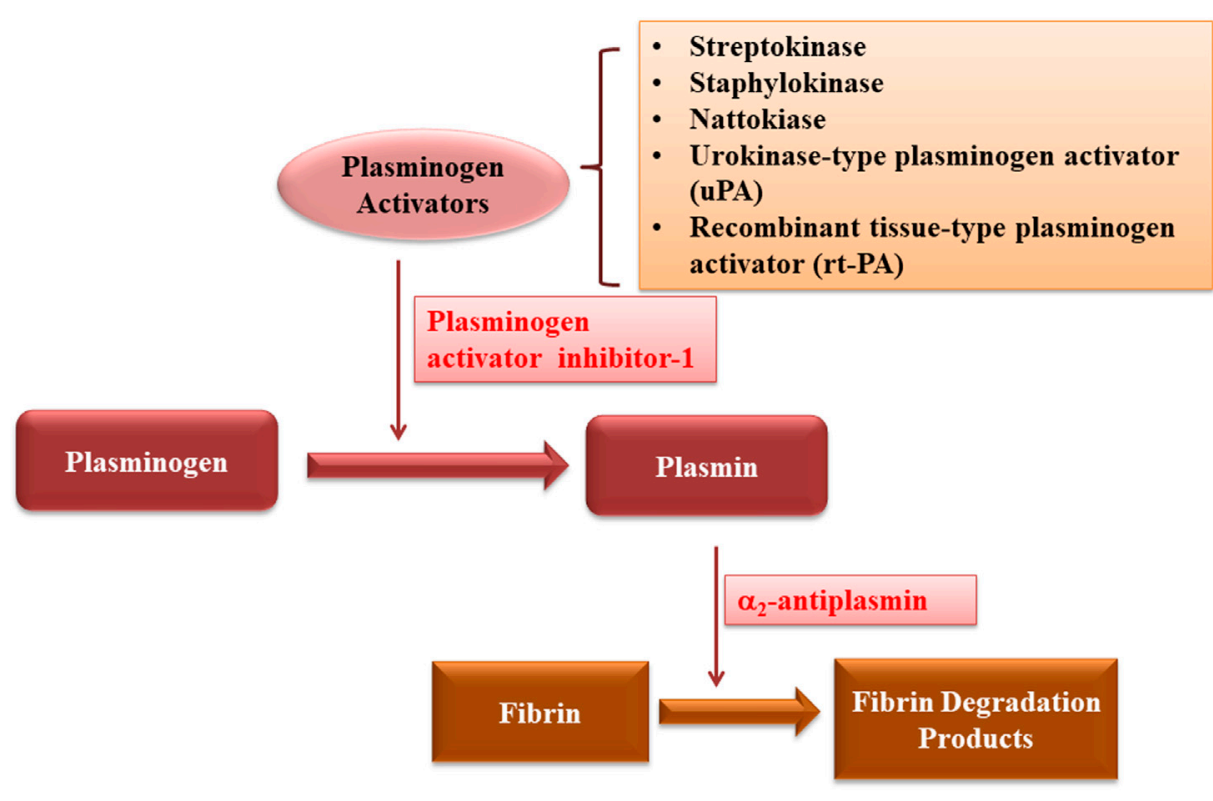

FIGURE 6 | Schematic diagram showing the mechanism of action of thrombolytic drugs.

TABLE 7 | Comparison of different thrombolytic drugs.

\begin{tabular}{|c|c|c|c|c|c|}
\hline Thrombolytic drugs & $\begin{array}{c}\text { Molecular } \\
\text { weight (kDa) }\end{array}$ & $\begin{array}{c}\text { Number of amino } \\
\text { acids }\end{array}$ & Domain structure & $\begin{array}{c}\text { Fibrin } \\
\text { specificity }\end{array}$ & $\begin{array}{l}\text { Plasminogen } \\
\text { activation }\end{array}$ \\
\hline Streptokinase & 47 & 414 & $3(\alpha, \beta$, and $\gamma)$ & No & Indirect \\
\hline Staphylokinase & 15.5 & 136 & 2 domains & Yes & Indirect \\
\hline Nattokinase & 27.7 & 275 & 1 domain & Yes & Direct \\
\hline Urokinase-type plasminogen activator & $54-33$ & 411 & 3 (GFD, KD, P) & No & Direct \\
\hline $\begin{array}{l}\text { Recombinant tissue-type plasminogen } \\
\text { activator }\end{array}$ & 70 & 527 & $5(\mathrm{~F}, \mathrm{EGF}, \mathrm{K} 1, \mathrm{~K} 2, \mathrm{P})$ & Yes & Direct \\
\hline
\end{tabular}

fibrinolytic enzymes, such as Streptokinase, Urokinase, Recombinant tissue plasminogen activator (rtPA), Reteplase, and Tenecteplase have been used for clinical application and are commercially available. While they exhibit benefits due to their fibrin specificity, prolonged plasma half-life, stability, resistance to PAI-1, less antigenicity, cost effectiveness and low bleeding complications, efforts are still needed to enhance their half-life, fibrin specificity, efficacy, biocompatibility and resistance to inhibition by plasma inhibitors as well as to reduce major side effects of bleeding and hemorrhage.

Among different sources, microbial fibrinolytic and thrombolytic enzymes have gathered more medical attention in previous years for their low-cost and large-scale production. Some of the microbial fibrinolytic such as Streptokinase, Urokinase, Recombinant tissue plasminogen activator (rtPA), Reteplase, and Tenecteplase have been approved for their clinical use. These drugs are potential to reduce the risk of death or reccurence of blood clots; however, their side effects, including major and minor haemorrhagic events, hemorrhagic transformation, brain edema, and stroke, have also been reported. There are also many other fibrinolytic enzymes from various sources that have been proven to be effective for thrombolytic therapy in vitro, and thus can also be used as potential drugs for anti-thrombotic therapy; however, their in vivo experimental studies and immunogenicity-based analysis are yet to be done.

In summary, utilizing fibrinolytic enzymes for antithrombolytic therapy is promising. However, while different approaches have been used to reduce their side effects, efforts are still needed to overcome the problems associated with bleeding, hemorrhage, and allergic reactions. Furthermore, further optimization of their production process is also needed in order to design safe and cost-effective drugs. Nevertheless, the use of fibrinolytic enzymes for thrombolytic therapy will be more promising and far better option in future.

\section{AUTHOR CONTRIBUTIONS}

FA performed investigation, wrote and edited the manuscript SW and VK: conceived the work, revised, and edited the manuscript. 


\section{FUNDING}

This work was supported by grants from the he Natural Science Foundation of Chongqing (cstc2018jcyjAX0411 and cstc2018jcyjAX0374) and the Fundamental Research Funds for the Central Universities (2019CDQYSW010).

\section{REFERENCES}

AdivitiyaBabbalMohanty, S., and Khasa, Y. P. (2018). Engineering of Deglycosylated and Plasmin Resistant Variants of Recombinant Streptokinase in Pichia pastoris. Appl. Microbiol. Biotechnol. 102 (24), 10561-10577. doi:10.1007/s00253-018-9402-x

Afifah, D. N., Sulchan, M., Syah, D., Yanti, Y., Suhartono, M. T., and Kim, J. H. (2014). Purification and Characterization of a Fibrinolytic Enzyme from Bacillus Pumilus 2.G Isolated from Gembus, an Indonesian Fermented Food. Prev. Nutr. Food. Sci. 19 (3), 213-219. doi:10.3746/pnf.2014.19.3.213

Ahmad, M. S., Noor, Z. M., and Ariffin, Z. Z. (2014). Isolation and Identification Fibrinolytic Protease Endophytic Fungi from Hibiscus Leaves in Shah Alam. Int. J. Biol. Vet. Agric. Food Eng. 8 (10), 1027-1030.

Akhtar, T., Hoq, M. M., and Mazid, M. A. (2017). Bacterial Proteases as Thrombolytics and Fibrinolytics. Dhaka Univ. J. Pharm. Sci. 16 (2), 255-269. 10.3329/dujps.v16i2.35265

Al Farraj, D. A., Kumar, T. S. J., Vijayaraghavan, P., Elshikh, M. S., Alkufeidy, R. M., Alkubaisi, N. A., et al. (2020). Enhanced Production, Purification and Biochemical Characterization of Therapeutic Potential Fibrinolytic Enzyme from a New Bacillus flexus from Marine Environment. J. King Saud Univ. Sci. 32 (7), 3174-3180. doi:10.1016/j.jksus.2020.09.004

Ali, M., Salim Hossain, M., Islam, M., Arman, S. I., Sarwar Raju, G., Dasgupta, P., et al. (2014). Aspect of Thrombolytic Therapy: A Review. ScientificWorldJournal 2014, 586510. doi:10.1155/2014/586510

Altes, P., Perez, P., Esteban, C., Sánchez Muñoz-Torrero, J. F., Aguilar, E., GarcíaDíaz, A. M., et al. (2018). Raised Fibrinogen Levels and Outcome in Outpatients with Peripheral Artery Disease. Angiology 69 (6), 507-512. doi:10.1177/ 0003319717739720

Aneja, R., Datt, M., Yadav, S., and Sahni, G. (2013). Multiple Exosites Distributed Across the Three Domains of Streptokinase Co-Operate to Generate High Catalytic Rates in the Streptokinase-Plasmin Activator Complex. Biochemistry 52 (49), 8957-8968. doi:10.1021/bi400142s

Anh, D. B. Q., Mi, N. T. T., Huy, D. N. A., and Van Hung, P. (2015). Isolation and Optimization of Growth Condition of Bacillus sp. from Fermented Shrimp Paste for High Fibrinolytic Enzyme Production. Arab J. Sci. Eng. 40 (1), 23-28. doi:10.1007/s13369-014-1506-8

Anusree, M., Swapna, K., Aguilar, C. N., and Sabu, A. (2020). Optimization of Process Parameters for the Enhanced Production of Fibrinolytic Enzyme by a Newly Isolated Marine Bacterium. Bioresour. Technol. Rep. 11, 100436. doi:10. 1016/j.biteb.2020.100436

Arabi, R., Roohvand, F., Norouzian, D., Sardari, S., Aghasadeghi, M. R., Khanahmad, H., et al. (2011). A Comparative Study on the Activity and Antigenicity of Truncated and Full-Length Forms of Streptokinase. Pol. J. Microbiol. 60 (3), 243-251. doi:10.33073/pjm-2011-034

Asada, Y., Yamashita, A., Sato, Y., and Hatakeyama, K. (2018). Thrombus Formation and Propagation in the Onset of Cardiovascular Events. J. Atheroscler. Thromb. 25 (8), 653-664. doi:10.5551/jat.RV17022

Baharifar, H., Khoobi, M., Arbabi Bidgoli, S., and Amani, A. (2020). Preparation of PEG-Grafted Chitosan/streptokinase Nanoparticles to Improve Biological Half-Life and Reduce Immunogenicity of the Enzyme. Int. J. Biol. Macromol. 143, 181-189. doi:10.1016/j.ijbiomac.2019.11.157

Bajaj, B. K., Sharma, N., and Singh, S. (2013). Enhanced Production of Fibrinolytic Protease from Bacillus cereus NS-2 Using Cotton Seed Cake as Nitrogen Source. Biocatal. Agric. Biotechnol. 2 (3), 204-209. doi:10.1016/j.bcab.2013.04.003

Bajaj, B. K., Singh, S., Khullar, M., Singh, K., and Bhardwaj, S. (2014). Optimization of Fibrinolytic Protease Production from Bacillus subtilis I-2 Using AgroResidues. Braz. Arch. Biol. Technol. 57 (1), 653-662. doi:10.1590/S15168913201402132

\section{ACKNOWLEDGMENTS}

Our intention is to summarize the state of art. However, due to space limitations, we would like to apologize to authors whose works are not cited here. Their contributions should not be considered less important than those that are cited.

Bannish, B. E., Chernysh, I. N., Keener, J. P., Fogelson, A. L., and Weisel, J. W. (2017). Molecular and Physical Mechanisms of Fibrinolysis and Thrombolysis from Mathematical Modeling and Experiments. Sci. Rep. 7 (1), 1-11. doi:10. 1038/s41598-017-06383-w

Bauer, K. A. (2013). Pros and Cons of New Oral Anticoagulants. Hematology 2013 (1), 464-470. doi:10.1182/asheducation-2013.1.464

Bi, H., Zhao, H., Lu, F., Zhang, C., Bie, X., and Lu, Z. (2015). Improvement of the Nutritional Quality and Fibrinolytic Enzyme Activity of Soybean Meal by Fermentation of Bacillus subtilis. J. Food Process. Pres. 39 (6), 1235-1242. doi:10.1111/jfpp.12340

Biji, G. D., Arun, A., Muthulakshmi, E., Vijayaraghavan, P., Arasu, M. V., and AlDhabi, N. A. (2016). Bio-Prospecting of Cuttle Fish Waste and Cow Dung for the Production of Fibrinolytic Enzyme from Bacillus cereus IND5 in Solid State Fermentation. 3 Biotech 6 (2), 231. doi:10.1007/s13205-016-0553-0

Blasi, F., and Carmeliet, P. (2002). uPAR: A Versatile Signalling Orchestrator. Nat. Rev. Mol. Cell Biol. 3 (12), 932-943. doi:10.1038/nrm977

Bokarewa, M., Jin, T., and Tarkowski, A. (2006). Staphylococcus aureus: Staphylokinase. Int. J. Biochem. Cell Biol. 38 (4), 504-509. doi:10.1016/j. biocel.2005.07.005

Boos, C. J., and Lip, G. (2006). Blood Clotting, Inflammation, and Thrombosis in Cardiovascular Events: Perspectives. Front. Biosci. 11, 328-336. doi:10.2741/ 1800

Bridge, K., Philippou, H., and Ariëns, R. (2014). Clot Properties and Cardiovascular Disease. Thromb. Haemost. 112 (11), 901-908. doi:10.1160/th14-02-0184

Burgazli, K. M., Atmaca, N., Mericliler, M., Parahuleva, M., Erdogan, A., and Daebritz, S. H. (2013). Deep Vein Thrombosis and Novel Oral Anticoagulants: A Clinical Review. Eur. Rev. Med. Pharmacol. Sci. 17 (23), 3123-3131.

Cesarman-Maus, G., and Hajjar, K. A. (2005). Molecular Mechanisms of Fibrinolysis. Br. J. Haematol. 129 (3), 307-321. doi:10.1111/j.1365-2141. 2005.05444.x

Chandramohan, M., Yee, C. Y., Kei Beatrice, P. H., Ponnaiah, P., Narendrakumar, G., and Samrot, A. V. (2019). Production, Characterization and Optimization of Fibrinolytic Protease from Bacillus pseudomycoides Strain MA02 Isolated from Poultry Slaughter House Soils. Biocatal. Agric. Biotechnol. 22, 101371. doi:10. 1016/j.bcab.2019.101371

Chang, C.-T., Wang, P.-M., Hung, Y.-F., and Chung, Y.-C. (2012). Purification and Biochemical Properties of a Fibrinolytic Enzyme from Bacillus subtilisFermented Red Bean. Food Chem. 133 (4), 1611-1617. doi:10.1016/j. foodchem.2012.02.061

Che, Z., Cao, X., Chen, G., and Liang, Z. (2020). An Effective Combination of Codon Optimization, Gene Dosage, and Process Optimization for High-Level Production of Fibrinolytic Enzyme in Komagataella phaffii (Pichia pastoris). BMC Biotechnol. 20 (1), 63. doi:10.1186/s12896-020-00654-7

Chelluboina, B., and Vemuganti, R. (2019). Chronic Kidney Disease in the Pathogenesis of Acute Ischemic Stroke. J. Cereb. Blood Flow Metab. 39 (10), 1893-1905. doi:10.1186/s40543-018-0143-310.1177/0271678x19866733

Chen, B., Huo, J., He, Z., He, Q., Hao, Y., and Chen, Z. (2013). Isolation and Identification of an Effective Fibrinolytic Strain Bacillus Subtilis FR-33 from the Chinese Doufuru and Primary Analysis of its Fibrinolytic Enzyme. Afr. J. Microbiol. Res. 7 (19), 2001-2009. doi:10.5897/AJMR12.282

Chen, H.-A., Ma, Y.-H., Hsu, T.-Y., and Chen, J.-P. (2020). Preparation of Peptide and Recombinant Tissue Plasminogen Activator Conjugated Poly(LacticCo-Glycolic Acid) (PLGA) Magnetic Nanoparticles for Dual Targeted Thrombolytic Therapy. Int. J. Mol. Sci. 21 (8), 2690. doi:10.3390/ ijms2 1082690

Chen, H., McGowan, E. M., Ren, N., Lal, S., Nassif, N., Shad-Kaneez, F., et al. (2018). Nattokinase: A Promising Alternative in Prevention and Treatment of Cardiovascular Diseases. Biomark Insights 13, 1177271918785130. doi:10.1177/ 1177271918785130 
Cheng, G., He, L., Sun, Z., Cui, Z., Du, Y., and Kong, Y. (2015). Purification and Biochemical Characterization of a Novel Fibrinolytic Enzyme from Streptomyces sp. P3. J. Microbiol. Biotechnol. 25 (9), 1449-1459. doi:10.4014/ jmb.1503.03015

Choi, D., Cha, W.-S., Park, N., Kim, H.-W., Lee, J. H., Park, J. S., et al. (2011). Purification and Characterization of a Novel Fibrinolytic Enzyme from Fruiting Bodies of Korean Cordyceps Militaris. Bioresour. Technol. 102 (3), 3279-3285. doi:10.1016/j.biortech.2010.10.002

Choi, J.-H., Kim, D.-W., Park, S.-E., Choi, B.-S., Sapkota, K., Kim, S., et al. (2014). Novel Thrombolytic Protease from Edible and Medicinal Plant Aster Yomena (Kitam.) Honda with Anticoagulant Activity: Purification and Partial Characterization. J. Biosci. Bioeng. 118 (4), 372-377. doi:10.1016/j.jbiosc. 2014.03.004

Choi, J.-H., Sapkota, K., Park, S.-E., Kim, S., and Kim, S.-J. (2013). Thrombolytic, Anticoagulant and Antiplatelet Activities of Codiase, a Bi-Functional Fibrinolytic Enzyme from Codium Fragile. Biochimie 95 (6), 1266-1277. doi:10.1016/j.biochi.2013.01.023

Chou, T.-L., Wu, C.-H., Huang, K.-F., and Wang, A. H.-J. (2013). Crystal Structure of a Trimeresurus Mucrosquamatus Venom Metalloproteinase Providing New Insights into the Inhibition by Endogenous Tripeptide Inhibitors. Toxicon 71, 140-146. doi:10.1016/j.toxicon.2013.05.009

Chung, D.-M., Choi, N.-S., Chun, H. K., Maeng, P. J., Park, S.-B., and Kim, S.-H. (2010a). A New Fibrinolytic Enzyme $(55 \mathrm{kDa})$ from Allium tuberosum: Purification, Characterization, and Comparison. J. Med. Food 13 (6), 1532-1536. doi:10.1089=jmf.2010.114410.1089/jmf.2010.1144

Chung, D.-M., Choi, N.-S., Maeng, P. J., Chun, H. K., and Kim, S.-H. (2010b). Purification and Characterization of a Novel Fibrinolytic Enzyme from Chive (Allium Tuberosum). Food Sci. Biotechnol. 19 (3), 697-702. doi:10.1007/ s10068-010-0098-7

Cintra, A. C. O., De Toni, L. G. B., Sartim, M. A., Franco, J. J., Caetano, R. C., Murakami, M. T., et al. (2012). Batroxase, a New Metalloproteinase from $B$. atrox Snake Venom with Strong Fibrinolytic Activity. Toxicon 60 (1), 70-82. doi:10.1016/j.toxicon.2012.03.018

Collen, D., and Lijnen, H. (1994). Staphylokinase, a Fibrin-Specific Plasminogen Activator with Therapeutic Potential? Blood 84, 680-686. doi:10.1182/blood. V84.3.680.680

da Silva, A. V., do Nascimento, J. M., Rodrigues, C. H., Silva Nascimento, D. C., Pedrosa Brandão Costa, R. M., de Araújo Viana Marques, D., et al. (2020). Partial Purification of Fibrinolytic and Fibrinogenolytic Protease from Gliricidia sepium Seeds by Aqueous Two-Phase System. Biocatal. Agric. Biotechnol. 27, 101669. doi:10.1016/j.bcab.2020.101669

da Silva, M. M., Rocha, T. A., de Moura, D. F., Chagas, C. A., de Aguiar Júnior, F. C. A., da Silva Santos, N. P., et al. (2019). Effect of Acute Exposure in Swiss Mice (Mus musculus) to a Fibrinolytic Protease Produced by Mucor Subtilissimus UCP 1262: An Histomorphometric, Genotoxic and Cytological Approach. Regul. Toxicol. Pharmacol. 103, 282-291. doi:10.1016/j.yrtph.2019.02.009

Danesh, J., Danesh, J., Lewington, S., Thompson, S. G., Lowe, G. D., Collins, R., et al. (2005). Plasma Fibrinogen Level and the Risk of Major Cardiovascular Diseases and Nonvascular Mortality: An Individual Participant Meta-Analysis. JAMA 294 (14), 1799-1809. doi:10.1001/jama.294.14.1799

Davidson, F. M. (1960). The Activation of Plasminogen by Staphylokinase: Comparison with Streptokinase. Biochem. J. 76 (1), 56-61. doi:10.1042/ bj0760056

de Barros, P. D. S., Silva, P. E. C. E., Nascimento, T. P., Costa, R. M. P. B., Bezerra, R. P., and Porto, A. L. F. (2020). Fibrinolytic Enzyme from Arthrospira Platensis Cultivated in Medium Culture Supplemented with Corn Steep Liquor. Int. J. Biol. Macromol. 164, 3446-3453. doi:10.1016/j.ijbiomac.2020.08.217

De Menezes, Y., Félix-Silva, J., da Silva-Júnior, A., Rebecchi, I., de Oliveira, A., Uchoa, A., et al. (2014). Protein-Rich Fraction of Cnidoscolus urens (L.) Arthur Leaves: Enzymatic Characterization and Procoagulant and Fibrinogenolytic Activities. Molecules 19 (3), 3552-3569. doi:10.3390/molecules19033552

de Souza, F. A. S. D., Sales, A. E., Costa e Silva, P. E., Bezerra, R. P., de Medeiros e Silva, G. M., de Araújo, J. M., et al. (2016). Optimization of Production, Biochemical Characterization and In Vitro Evaluation of the Therapeutic Potential of Fibrinolytic Enzymes from a New Bacillus amyloliquefaciens. Macromol. Res. 24 (7), 587-595. doi:10.1007/s13233-016-4089-2

Dhamodharan, D., Jemimah Naine, S., Merlyn Keziah, S., and Subathra Devi, C. (2019). Novel Fibrinolytic Protease Producing Streptomyces radiopugnans
VITSD8 from Marine Sponges. Mar. Drugs 17 (3), 164. doi:10.3390/ md17030164

Doolittle, R. F. (2010). "Fibrinogen and Fibrin(ELS)," in Encyclopedia of Life Sciences (ELS), Chichester: John Wiley \& Sons, Ltd.

Dubey, R., Kumar, J., Agrawala, D., Char, T., and Pusp, P. (2011). Isolation, Production, Purification, Assay and Characterization of Fibrinolytic Enzymes (Nattokinase, Streptokinase and Urokinase) from Bacterial Sources. Afr. J. Biotechnol. 10 (8), 1408-1420. doi:10.5897/AJB10.1268

Flemmig, M., and Melzig, M. F. (2012). Serine-Proteases as Plasminogen Activators in Terms of Fibrinolysis. J. Pharm. Pharmacol. 64 (8), 1025-1039. doi:10.1111/j. 2042-7158.2012.01457.x

Fox, J. W., and Serrano, S. M. T. (2005). Structural Considerations of the Snake Venom Metalloproteinases, Key Members of the M12 Reprolysin Family of Metalloproteinases. Toxicon 45 (8), 969-985. doi:10.1016/j.toxicon.2005.02.012

Fox, J. W., and Serrano, S. M. T. (2009). Timeline of Key Events in Snake Venom Metalloproteinase Research. J. Proteomics 72 (2), 200-209. doi:10.1016/j.jprot. 2009.01.015

Franchini, M., and Mannucci, P. M. (2008). Venous and Arterial Thrombosis: Different Sides of the Same Coin? Eur. J. Intern. Med. 19 (7), 476-481. doi:10. 1016/j.ejim.2007.10.019

Fu, T., Yang, F., Zhu, H., Zhu, H., and Guo, L. (2016). Rapid Extraction and Purification of Lumbrokinase from Lumbricus Rubellus Using a Hollow Fiber Membrane and Size Exclusion Chromatography. Biotechnol. Lett. 38 (2), 251-258. doi:10.1007/s10529-015-1979-X

Fu, Z., Zhang, L., Liu, X., Zhang, Y., Zhang, Q., Li, X., et al. (2013). Comparative Proteomic Analysis of the Sun- and Freeze-Dried Earthworm Eisenia fetida with Differentially Thrombolytic Activities. J. Proteomics 83, 1-14. doi:10.1016/ j.jprot.2013.02.028

Furie, B., and Furie, B. C. (2008). Mechanisms of Thrombus Formation. N. Engl. J. Med. 359 (9), 938-949. doi:10.1056/NEJMra0801082

Gad, R. G., Nirmala, S., and Sivvaswamy, S. N. (2014). Studies on a Fibrinolytic Enzyme from Bacillus Species. Indian J. Sci. Technol. 7 (10), 1632-1642. doi:10. 17485/ijst/2014/v7i10.12

Gerheim, E. B. (1948). Staphlococcal Coagulation and Fibrinolysis. Nature 162 (4123), 732. doi:10.1038/162732a0

Girón, M. E., Guerrero, B., Salazar, A. M., Sánchez, E. E., Alvarez, M., and Rodríguez-Acosta, A. (2013). Functional Characterization of Fibrinolytic Metalloproteinases (Colombienases) Isolated from Bothrops Colombiensis Venom. Toxicon 74, 116-126. doi:10.1016/j.toxicon.2013.07.025

Glanville, K. (1963). A Simple Method of Purifying Staphylokinase. Biochem. J. 88 (1), 11-14. doi:10.1042/bj0880011

Gross, P. L., and Weitz, J. I. (2008). New Anticoagulants for Treatment of Venous Thromboembolism. Arterioscler. Thromb. Vasc. Biol. 28 (3), 380-386. doi:10. 1161/ATVBAHA.108.162677

Gue, Y., and Gorog, D. (2017). Importance of Endogenous Fibrinolysis in Platelet Thrombus Formation. Int. J. Mol. Sci. 18 (9), 1850. doi:10.3390/ijms18091850

Güner, A., Kalçik, M., Aykan, A. Ç., Gürsoy, M. O., Kalkan, A. K., Astarcioglu, M. A., et al. (2020). Clinical Safety and Efficacy of Thrombolytic Therapy with Low-Dose Prolonged Infusion of Tissue Type Plasminogen Activator in Patients with Intermediate-High Risk Pulmonary Embolism. Blood Coagul. Fibrinolysis 31 (8). doi:10.1097/mbc.0000000000000960

Hamed, M. B., El-Badry, M. O., Kandil, E. I., Borai, I. H., and Fahmy, A. S. (2020). A Contradictory Action of Procoagulant Ficin by a Fibrinolytic Serine Protease from Egyptian Ficus carica Latex. Biotechnol. Rep. (Amst). 27, e00492. doi:10. 1016/j.btre.2020.e00492

Hasanpour, A., Esmaeili, F., Hosseini, H., and Amani, A. (2021). Use of mPEGPLGA Nanoparticles to Improve Bioactivity and Hemocompatibility of Streptokinase: In-Vitro and In-Vivo Studies. Mater. Sci. Eng. C Mater. Biol. Appl. 118, 111427. doi:10.1016/j.msec.2020.111427

Heo, K., Cho, K. M., Lee, C. K., Kim, G. M., Shin, J.-H., Kim, J. S., et al. (2013). Characterization of a Fibrinolytic Enzyme Secreted by Bacillus amyloliquefaciens $\mathrm{CB} 1$ and its Gene Cloning. J. Microbiol. Biotechnol. 23 (7), 974-983. doi:10.4014/jmb.1302.02065

Hodgkinson, C. P., and Ye, S. (2011). Toll-Like Receptors, Their Ligands, and Atherosclerosis. ScientificWorldJournal 11, 437-453. doi:10.1100/tsw. 2011.36

Hu, Y., Yu, D., Wang, Z., Hou, J., Tyagi, R., Liang, Y., et al. (2019). Purification and Characterization of a Novel, Highly Potent Fibrinolytic Enzyme from Bacillus 
subtilis DC27 Screened from Douchi, a Traditional Chinese Fermented Soybean Food. Sci. Rep. 9 (1), 1-10. doi:10.1038/s41598-019-45686-y

Huang, S., Pan, S., Chen, G., Huang, S., Zhang, Z., Li, Y., et al. (2013). Biochemical Characteristics of a Fibrinolytic Enzyme Purified from a Marine Bacterium, Bacillus subtilis HQS-3. Int. J. Biol. Macromol. 62, 124-130. doi:10.1016/j. ijbiomac.2013.08.048

Huy, D., Hao, P., and Hung, P. (2016). Screening and Identification of Bacillus sp. Isolated from Traditional Vietnamese Soybean-Fermented Products for High Fibrinolytic Enzyme Production. Int. Food Res. J. 23 (1), 326-331.

Ito, K. (2020). Effect of Water-Extractive Components from Funazushi, a Fermented Crucian Carp, on the Activity of Fibrinolytic Factors. J. Sci. Food Agric. 100 (6), 2482-2487. doi:10.1002/jsfa.10269

Jhample, S. B., Bhagwat, P. K., and Dandge, P. B. (2015). Statistical Media Optimization for Enhanced Production of Fibrinolytic Enzyme from Newly Isolated Proteus Penneri SP-20. Biocatal. Agric. Biotechnol. 4 (3), 370-379. doi:10.1016/j.bcab.2015.05.006

Jo, H.-D., Lee, H.-A., Jeong, S.-J., and Kim, J.-H. (2011). Purification and Characterization of a Major Fibrinolytic Enzyme from Bacillus amyloliquefaciens MJ5-41 Isolated from Meju. J. Microbiol. Biotechnol. 21 (11), 1166-1173. doi:10.4014/jmb.1106.06008

Johnson, Y., Suhartono, M. T., and Lay, B. W. (2015). Isolation and Purification of a Fibrinolytic Enzyme from Bacterial Strain Isolated from Tuak, an Indonesian Palm Wine. Int. J. Pharma Bio. Sci. 6 (4), B988-B996.

Joji, K., Santhiagu, A., and Salim, N. (2019). Computational Modeling of Culture media for Enhanced Production of Fibrinolytic Enzyme from Marine Bacterium Fictibacillus sp. Strain SKA27 and In Vitro Evaluation of Fibrinolytic Activity. 3 Biotech. 9 (9), 1-14. doi:10.1007/s13205-019-1853-y

Ju, X., Cao, X., Sun, Y., Wang, Z., Cao, C., Liu, J., et al. (2012). Purification and Characterization of a Fibrinolytic Enzyme from Streptomyces sp. XZNUM 00004. World J. Microbiol. Biotechnol. 28 (7), 2479-2486. doi:10.1007/s11274012-1055-9

Kadir, R. R. A., and Bayraktutan, U. (2020). Urokinase Plasminogen Activator: A Potential Thrombolytic Agent for Ischaemic Stroke. Cell Mol. Neurobiol. 40 (3), 347-355. doi:10.1007/s10571-019-00737-w

Kang, S.-R., Choi, J.-H., Kim, D.-W., Park, S.-E., Sapkota, K., Kim, S., et al. (2016). A Bifunctional Protease from Green Alga Ulva Pertusa with Anticoagulant Properties: Partial Purification and Characterization. J. Appl. Phycol. 28 (1), 599-607. doi:10.1007/s10811-015-0550-4

Kapetanios, D., Karkos, C. D., Pliatsios, I., Mitka, M., Giagtzidis, I. T., Konstantinidis, K., et al. (2019). Association Between Perioperative Fibrinogen Levels and the Midterm Outcome in Patients Undergoing Elective Endovascular Repair of Abdominal Aortic Aneurysms. Ann. Vasc. Surg. 56, 202-208. doi:10.1016/j.avsg.2018.09.021

Kazemi, F., Arab, S. S., Mohajel, N., Keramati, M., Niknam, N., Aslani, M. M., et al. (2019). Computational Simulations Assessment of Mutations Impact on Streptokinase (SK) from a Group G Streptococci with Enhanced Activity Insights into the Functional Roles of Structural Dynamics Flexibility of SK and Stabilization of SK-Mplasmin Catalytic Complex. J. Biomol. Struct. Dyn. 37 (8), 1944-1955. doi:10.1080/07391102.2018.1472668

Khursade, P. S., Galande, S. H., Shiva Krishna, P., and Prakasham, R. S. (2019). Stenotrophomonas maltophilia Gd2: A Potential and Novel Isolate for Fibrinolytic Enzyme Production. Saudi J. Biol. Sci. 26 (7), 1567-1575. doi:10.1016/j.sjbs.2018.10.014

Kim, C., Ri, K., and Choe, S. (2020). A Novel Fibrinolytic Enzymes from the Korean Traditional Fermented Food-Jotgal: Purification and Characterization. J. Food Biochem. 44 (7), el3255. doi:10.1111/jfbc.13255

Kim, D.-W., Choi, J.-H., Park, S.-E., Kim, S., Sapkota, K., and Kim, S.-J. (2015). Purification and Characterization of a Fibrinolytic Enzyme from Petasites japonicus. Int. J. Biol. Macromol. 72, 1159-1167. doi:10.1016/j.ijbiomac.2014. 09.046

Kim, D.-W., Sapkota, K., Choi, J.-H., Kim, Y.-S., Kim, S., and Kim, S.-J. (2013). Direct Acting Anti-Thrombotic Serine Protease from Brown Seaweed Costaria costata. Process Biochem. 48 (2), 340-350. doi:10.1016/j.procbio.2012.12.012

Kim, H. C., Choi, B.-S., Sapkota, K., Kim, S., Lee, H. J., Yoo, J. C., et al. (2011). Purification and Characterization of a Novel, Highly Potent Fibrinolytic Enzyme from Paecilomyces Tenuipes. Process Biochem. 46 (8), 1545-1553. doi:10.1016/j.procbio.2011.04.005
Klovaite, J., Nordestgaard, B. G., Tybjærg-Hansen, A., and Benn, M. (2013). Elevated Fibrinogen Levels are Associated with Risk of Pulmonary Embolism, but not with Deep Venous Thrombosis. Am. J. Respir. Crit. Care Med. 187 (3), 286-293. doi:10.1164/rccm.201207-1232OC

Kneeland, P. P., and Fang, M. C. (2010). Current Issues in Patient Adherence and Persistence: Focus on Anticoagulants for the Treatment and Prevention of Thromboembolism. Patient Prefer Adherence 4, 51-60. doi:10.2147/ppa.s6101

Kolev, K., and Machovich, R. (2003). Molecular and Cellular Modulation of Fibrinolysis. Thromb. Haemost. 89 (04), 610-621. doi:10.1055/s-0037-1613567

Kotb, E. (2012). Fibrinolytic Bacterial Enzymes with Thrombolytic Activity. Berlin, Germany: Springer, 1-74.

Kotb, E., Helal, G. E.-D. A., and Edries, F. M. (2015). Screening for Fibrinolytic Filamentous Fungi and Enzymatic Properties of the Most Potent Producer, Aspergillus brasiliensis AUMC 9735. Biologia 70 (12), 1565-1574. doi:10.1515/ biolog-2015-0192

Krishnamurthy, A., Belur, P. D., and Subramanya, S. B. (2018). Methods Available to Assess Therapeutic Potential of Fibrinolytic Enzymes of Microbial Origin: A Review. J. Anal. Sci. Technol. 9 (1), 10. doi:10.1186/s40543-018-0143-3

Krishnamurthy, A., Belur, P., Rai, P., and Rekha, P. (2017). Production of Fibrinolytic Enzyme by the Marine Isolate Serratia marcescens subsp. sakuensis and its In-Vitro Anticoagulant and Thrombolytic Potential. J. Pure Appl. Microbiol. 11 (4), 1987-1998. doi:10.22207/JPAM.11.4.41

Kumar, S. S., Haridas, M., and Abdulhameed, S. (2020). A Novel Fibrinolytic Enzyme from Marine Pseudomonas aeruginosa KU1 and its Rapid In Vivo Thrombolysis with Little Haemolysis. Int. J. Biol. Macromol. 162, 470-479. doi:10.1016/j.ijbiomac.2020.06.178

Kumar, S. S., Haridas, M., and Sabu, A. (2018). Process Optimization for Production of a Fibrinolytic Enzyme from Newly Isolated Marine Bacterium Pseudomonas aeruginosa KU1. Biocatal. Agric. Biotechnol. 14, 33-39. doi:10. 1016/j.bcab.2018.02.001

Kunadian, V., and Gibson, C. M. (2012). Thrombolytics and Myocardial Infarction. Cardiovasc. Ther. 30 (2), e81-e88. doi:10.1111/j.1755-5922.2010. 00239.x

Lack, C. H. (1948). Staphylokinase : An Activator of Plasma Protease. Nature 161 (4093), 559-560. doi:10.1038/161559b0

Lampe, B. J., and English, J. C. (2016). Toxicological Assessment of Nattokinase Derived from Bacillus subtilis var. natto. Food Chem. Toxicol. 88, 87-99. doi:10. 1016/j.fct.2015.12.025

Lapsongphon, N., Rodtong, S., and Yongsawatdigul, J. (2013). Spent Brewery Yeast Sludge as a Single Nitrogen Source for Fibrinolytic Enzyme Production of Virgibacillus sp. SK37. Food Sci. Biotechnol. 22 (1), 71-78. doi:10.1007/s10068013-0010-3

Lee, H.-J., and Im, H.-N. (2010). Soluble Expression and Purification of Human Tissue-Type Plasminogen Activator Protease Domain. Bull. Korean Chem. Soc. 31 (9), 2607-2612. doi:10.5012/BKCS.2010.31.9.2607

Lijnen, H. R., Van Hoef, B., Osamu, M., and Collen, D. (1992). On the Molecular Interactions Between Plasminogen-Staphylokinase, Alpha 2-Antiplasmin and Fibrin. Biochim. Biophys. Acta. 1118 (2), 144-148. doi:10.1016/0167-4838(92) 90142-Z

Lippi, G., Franchini, M., and Targher, G. (2011). Arterial Thrombus Formation in Cardiovascular Disease. Nat. Rev. Cardiol. 8 (9), 502-512. doi:10.1038/nrcardio. 2011.91

Liu, J., Zhang, Y., Lavie, C. J., Tabung, F. K., Xu, J., Hu, Q., et al. (2020). Associations of C-Reactive Protein and Fibrinogen with Mortality from AllCauses, Cardiovascular Disease and Cancer Among U.S. Adults. Prev. Med. 139, 106044. doi:10.1016/j.ypmed.2020.106044

Liu, X.-l., Zheng, X.-q., Qian, P.-z., Kopparapu, N.-k., Deng, Y.-p., Nonaka, M., et al. (2014). Purification and Characterization of a Novel Fibrinolytic Enzyme from Culture Supernatant of Pleurotus ostreatus. J. Microbiol. Biotechnol. 24 (2), 245-253. doi:10.4014/jmb.1307.07063

Liu, X., Kopparapu, N.-K., Li, Y., Deng, Y., and Zheng, X. (2017). Biochemical Characterization of a Novel Fibrinolytic Enzyme from Cordyceps militaris. Int. J. Biol. Macromol. 94, 793-801. doi:10.1016/j.ijbiomac.2016.09.048

Liu, X. l., Kopparapu, N. k., Zheng, H. c., Katrolia, P., Deng, Y. p., and Zheng, X. q. (2016). Purification and Characterization of a Fibrinolytic Enzyme from the Food-Grade Fungus, Neurospora sitophila. J. Mol. Catal. B Enzym. 134, 98-104. doi:10.1016/j.molcatb.2016.10.006 
Liu, X. L., Zheng, X. Q., and Zhang, J. K. (2012). Production of a Fibrinolytic Enzyme from Coprinus comatus YY-20. Appl. Mech. Mater. 138-139, 1195-1201. doi:10.4028/www.scientific.net/AMM.138-139.1195

Lu, F., Lu, Z., Bie, X., Yao, Z., Wang, Y., Lu, Y., et al. (2010). Purification and Characterization of a Novel Anticoagulant and Fibrinolytic Enzyme Produced by Endophytic Bacterium Paenibacillus polymyxa EJS-3. Thromb. Res. 126 (5), e349-e355. doi:10.1016/j.thromres.2010.08.003

Lucy, J., Raharjo, P. F., Elvina, E., Florencia, L., Susanti, A. I., and Pinontoan, R. (2019). Clot Lysis Activity of Bacillus subtilis G8 Isolated from Japanese Fermented Natto Soybeans. Appl. Food Biotechnol. 6 (2), 101-109. doi:10. 22037/afb.v6i2.22479

Lundberg, A. M., and Hansson, G. K. (2010). Innate Immune Signals in Atherosclerosis. Clin. Immunol. 134 (1), 5-24. doi:10.1016/j.clim.2009.07.016

Macfarlane, R. G., and Pilling, J. (1947). Fibrinolytic Activity of Normal Urine. Nature 159 (4049), 779. doi:10.1038/159779a0

Mackman, N. (2008). Triggers, Targets and Treatments for Thrombosis. Nature 451 (7181), 914-918. doi:10.1038/nature06797

Maeda, H., Mizutani, O., Yamagata, Y., Ichishima, E., and Nakajima, T. (2001). Alkaline-Resistance Model of Subtilisin ALP I, a Novel Alkaline Subtilisin. J. Biochem. 129 (5), 675-682. doi:10.1093/oxfordjournals.jbchem.a002906

Maheshwari, N., Kantipudi, S., Maheshwari, A., Arora, K., Vandana, N., Kwatra, N., et al. (2016). Amino-Terminal Fusion of Epidermal Growth Factor 4,5,6 Domains of Human Thrombomodulin on Streptokinase Confers Antireocclusion Characteristics Along with Plasmin-Mediated Clot Specificity. PLoS One 11 (3), e0150315. doi:10.1371/journal.pone.0150315

Mahmood, N., Mihalcioiu, C., and Rabbani, S. A. (2018). Multifaceted Role of the Urokinase-Type Plasminogen Activator (uPA) and its Receptor (uPAR): Diagnostic, Prognostic, and Therapeutic Applications. Front. Oncol. 8, 24. doi:10.3389/fonc.2018.00024

Majumdar, S., Chattopadhyay, P., and Mukherjee, A. K. (2016). In Vivo Anticoagulant and Thrombolytic Activities of a Fibrinolytic Serine Protease (Brevithrombolase) with the K-Carrageenan-Induced Rat Tail Thrombosis Model. Clin. Appl. Thromb. Hemost. 22 (6), 594-598. doi:10.1177/ 1076029615569567

Mander, P., Cho, S. S., Simkhada, J. R., Choi, Y. H., and Yoo, J. C. (2011). A Low Molecular Weight Chymotrypsin-Like Novel Fibrinolytic Enzyme from Streptomyces sp. CS624. Process Biochem. 46 (7), 1449-1455. doi:10.1016/j. procbio.2011.03.016

Meshram, V., Saxena, S., Paul, K., Gupta, M., and Kapoor, N. (2017). Production, Purification and Characterisation of a Potential Fibrinolytic Protease from Endophytic Xylaria Curta by Solid Substrate Fermentation. Appl. Biochem. Biotechnol. 181 (4), 1496-1512. doi:10.1007/s12010-016-2298-y

Meshram, V., Saxena, S., and Paul, K. (2016). Xylarinase: A Novel Clot Busting Enzyme from an Endophytic Fungus Xylaria curta. J. Enzyme Inhib. Med. Chem. 31 (6), 1502-1511. doi:10.3109/14756366.2016.1151013

Min, S.-K., Han, S.-M., Jang, J.-S., and Kim, J.-K. (2016). Stimulatory Effect of an Algal Fucoidan on the Release of Vascular Endothelial Tissue-type Plasminogen Activator as a Mechanism of Fucoidan-Mediated Thrombolysis. Blood Coagul. Fibrinolysis 27 (5), 594-596. doi:10.1097/MBC.0000000000000522

Mine, Y., Kwan Wong, A. H., and Jiang, B. (2005). Fibrinolytic Enzymes in Asian Traditional Fermented Foods. Food Res. Int. 38 (3), 243-250. doi:10.1016/j. foodres.2004.04.008

Moharam, M. E., El-Bendary, M. A., El-Beih, F., Hassanin Easa, S. M., Abo Elsoud, M. M., Azzam, M. I., et al. (2019). Optimization of Fibrinolytic Enzyme Production by Newly Isolated Bacillus subtilis Egy Using Central Composite Design. Biocatal. Agric. Biotechnol. 17, 43-50. doi:10.1016/j. bcab.2018.11.003

Moon, S.-M., Kim, J.-S., Kim, H.-J., Choi, M. S., Park, B. R., Kim, S.-G., et al. (2014). Purification and Characterization of a Novel Fibrinolytic a Chymotrypsin like Serine Metalloprotease from the Edible Mushroom, Lyophyllum shimeji. J. Biosci. Bioeng. 117 (5), 544-550. doi:10.1016/j.jbiosc.2013.10.019

Mukherjee, A. K., Rai, S. K., Thakur, R., Chattopadhyay, P., and Kar, S. K. (2012). Bafibrinase: A Non-Toxic, Non-Hemorrhagic, Direct-Acting Fibrinolytic Serine Protease from Bacillus sp. Strain AS-S20-I Exhibits In Vivo Anticoagulant Activity and Thrombolytic Potency. Biochimie 94 (6), 1300-1308. doi:10.1016/j.biochi.2012.02.027

Nagata, C., Wada, K., Tamura, T., Konishi, K., Goto, Y., Koda, S., et al. (2017). Dietary Soy and Natto Intake and Cardiovascular Disease Mortality in Japanese
Adults: The Takayama Study. Am. J. Clin. Nutr. 105 (2), 426-431. doi:10.3945/ ajen.116.137281

Nailufar, F., Tjandrawinata, R. R., and Suhartono, M. T. (2016). Thrombus Degradation by Fibrinolytic Enzyme of Stenotrophomonas sp. Originated from Indonesian Soybean-Based Fermented Food on Wistar Rats. Adv. Pharmacol. Sci. 2016, 4206908. doi:10.1155/2016/4206908

Narasimhan, M. K., Chandrasekaran, M., and Rajesh, M. (2015). Fibrinolytic Enzyme Production by Newly Isolated Bacillus cereus SRM-001 with Enhanced In-Vitro Blood Clot Lysis Potential. J. Gen. Appl. Microbiol. 61 (5), 157-164. doi:10.2323/jgam.61.157

Narasimhan, M. K., Ethiraj, S., Krishnamurthi, T., and Rajesh, M. (2018). Purification, Biochemical, and thermal Properties of Fibrinolytic Enzyme Secreted by Bacillus cereus SRM-001. Prep. Biochem. Biotechnol. 48 (1), 34-42. doi:10.1080/10826068.2017.1387560

Nascimento, T. P., Sales, A. E., Porto, C. S., Brandão, R. M. P., de Campos-Takaki, G. M., Teixeira, J. A. C., et al. (2016). Purification of a Fibrinolytic Protease from Mucor subtilissimus UCP 1262 by Aqueous Two-Phase Systems (PEG/Sulfate). J. Chromatogr. B 1025, 16-24. doi:10.1016/j.jchromb.2016.04.046

Nascimento, T. P., Sales, A. E., Porto, C. S., Brandão, R. M. P., Takaki, G. M. C., Teixeira, J. A. C., et al. (2015). Production and Characterization of New Fibrinolytic Protease from Mucor subtillissimus UCP 1262 in Solid-State Fermentation. Adv. Enzyme Res. 3 (3), 81-91. doi:10.4236/aer.2015.33009

Naveena, B., Gopinath, K. P., Sakthiselvan, P., and Partha, N. (2012). Enhanced Production of Thrombinase by Streptomyces venezuelae: Kinetic Studies on Growth and Enzyme Production of Mutant Strain. Bioresour. Technol. 111, 417-424. doi:10.1016/j.biortech.2012.02.056

Nedaeinia, R., Faraji, H., Javanmard, S. H., Ferns, G. A., Ghayour-Mobarhan, M., Goli, M., et al. (2020). Bacterial Staphylokinase as a Promising ThirdGeneration Drug in the Treatment for Vascular Occlusion. Mol. Biol. Rep. 47 (1), 819-841. doi:10.1007/s11033-019-05167-x

Nguimbi, E., Ahombo, G., Moyen, R., Ampa, R., Vouidibio, A., Ontsira, E., et al. (2014). Optimization of Growth, Fibrinolytic Enzyme Production and PCR Amplification of Encoding Fibrinolytic Enzyme Gene in Bacillus amyloliquefaciens Isolated from Ntoba Mbodi at Brazzaville. Int. J. Sci. Res. 3 (11), 2799-2803.

Ningthoujam, D., and Thokchom, S. (2016). Screening of Fibrinolytic Enzymes from Microorganisms Especially Actinomycetes from Different Biotopes in Manipur. Arch. Clin. Microbiol. 7, 21. doi:10.4172/1989-8436.100050

Noori, H., and Aziz, G. (2020). Purification, Characterization, and Evaluation of Fibrinolytic Activity of Staphylokinase from Locally Isolated Staphylococcus aureus GH38. Iraqi J. Agric. Sci. 51 (4), 1195-1203. doi:10.36103/ijas.v51i4.1098

Ok, M., and Choi, Y.-S. (2005). Screening of Fibrinolytic Enzyme Producing from Microorganisms in Korean Fermented Soybean Paste and Optimum Conditions of Enzyme Production. Korean J. Food Preserv. 12 (6), 643-649.

Páblo, E. C. S., de Souza, F. A. S. D., and de Barros, R. C. (2017). Enhanced Production of Fibrinolytic Protease from Microalgae Chlorella vulgaris Using Glycerol and Corn Steep Liquor as Nutrient. Ann. Microbiol. Res. 1 (1), 9-19. doi:10.36959/958/564

Palanivel, P., Ashokkumar, L., and Balagurunathan, R. (2013). Production, Purification and Fibrinolytic Characterization of Alkaline Protease from Extremophilic Soil Fungi. Int. J. Pharm. Bio Sci. 4 (2), 101-110.

Pan, S., Chen, G., Wu, R., Cao, X., and Liang, Z. (2019a). Non-Sterile Submerged Fermentation of Fibrinolytic Enzyme by Marine Bacillus subtilis Harboring Antibacterial Activity with Starvation Strategy. Front. Microbiol. 10, 1025. doi:10.3389/fmicb.2019.01025

Pan, S., Chen, G., Zeng, J., Cao, X., Zheng, X., Zeng, W., et al. (2019b). Fibrinolytic Enzyme Production from Low-Cost Substrates by Marine Bacillus subtilis: Process Optimization and Kinetic Modeling. Biochem. Eng. J. 141, 268-277. doi:10.1016/j.bej.2018.11.002

Park, C.-S., Kim, D. H., Lee, W.-Y., Kang, D.-O., Song, J. J., and Choi, N.-S. (2013). Identification of Fibrinogen-Induced Nattokinase WRL101 from Bacillus Subtilis WRL101 Isolated from Doenjang. Afr. J. Microbiol. Res. 7 (19), 1983-1992. doi:10.5897/AJMR12.041

Parry, D. J., Al-Barjas, H. S., Chappell, L., Rashid, T., Ariëns, R. A. S., and Scott, D. J. A. (2009). Haemostatic and Fibrinolytic Factors in Men with a Small Abdominal Aortic Aneurysm. Br. J. Surg. 96 (8), 870-877. doi:10.1002/bjs.6632

Patel, G. K., Kawale, A. A., and Sharma, A. K., (2012). Purification and Physicochemical Characterization of a Serine Protease with Fibrinolytic 
Activity from Latex of a Medicinal Herb Euphorbia Hirta. Plant Physiol. Biochem. 52, 104-111. doi:10.1016/j.plaphy.2011.12.004

Poliakov, A., Tkachuk, V., Ovchinnikova, T., Potapenko, N., Bagryantsev, S., and Stepanova, V. (2001). Plasmin-Dependent Elimination of the Growth-FactorLike Domain in Urokinase Causes its Rapid Cellular Uptake and Degradation. Biochem. J. 355 (3), 639-645. doi:10.1042/bj3550639

Prabhu, N., Sangeetha, K., Sangeetha, K., Jayanthi, C., and Gajendran, T. (2020). Exploration of New Effective Fibrinolytic Agent from Alcaligenes aquatilis PJS_1 from Polluted Soil. J. Environ. Biol. 41 (3), 572-580. doi:10.22438/jeb/41/ 3/MRN-1111

Prihanto, A. A., and Firdaus, M. (2019). Proteolytic and Fibrinolytic Activities of Halophilic Lactic Acid Bacteria from Two Indonesian Fermented Foods. J. Microbiol. Biotechnol. Food Sci. 2 (5), 2291-2293.

Pulicherla, K. K., Kumar, A., Gadupudi, G. S., Kotra, S. R., and Rao, K. R. (2013). In Vitro characterization of a Multifunctional Staphylokinase Variant with Reduced Reocclusion, Produced from Salt Inducible E. coli GJ1158. Biomed. Res. Int. 2013, 297305. doi:10.1155/2013/297305

Raju, E. V. N., and Divakar, G. (2013a). Bacillus cereus GD 55 Strain Improvement by Physical and Chemical Mutagenesis for Enhanced Production of Fibrinolytic Protease. Int. J. Pharma Sci. Res. 4 (5), 81-93.

Raju, E. V. N., and Divakar, G. (2013b). Screening and Isolation of Fibrinolytic Protease Producing Mesophilic Bacteria from Slaughter Houses in Bangalore. Int. J. Pharm. Sci. Res. 4 (9), 3625. doi:10.13040/IJPSR.0975-8232.4(9).3625-29

Ram, K. S., Peravali, J. B., Kumar, A., Rao, K. S., and Pulicherla, K. (2013). Staphylokinase: A Boon in Medical Sciences-Review. Mintage J. Pharmaceut. Med. Sci. 2 (2), 28-34.

Reininger, A. J., Bernlochner, I., Penz, S. M., Ravanat, C., Smethurst, P., Farndale, R. W., et al. (2010). A 2-Step Mechanism of Arterial Thrombus Formation Induced by Human Atherosclerotic Plaques. J. Am. Coll. Cardiol. 55 (11), 1147-1158. doi:10.1016/j.jacc.2009.11.051

Roohvand, F. (2018). Study Break: Streptokinase for Treatment of Thrombotic Disorders: The End? or the End of the Beginning? Iran Biomed. J. 22 (3), 140-141.

Rovati, J. I., Delgado, O. D., Figueroa, L. I. C., and Fariña, J. I. (2009). A Novel Source of Fibrinolytic Activity: Bionectria sp., an Unconventional EnzymeProducing Fungus Isolated from Las Yungas Rainforest (Tucumán, Argentina). World J. Microbiol. Biotechnol. 26 (1), 55-62. doi:10.1007/s11274-009-0142-z

Sales, A. E., de Souza, F. A. S. D., Teixeira, J. A., Porto, T. S., and Porto, A. L. F. (2013). Integrated Process Production and Extraction of the Fibrinolytic Protease from Bacillus sp. UFPEDA 485. Appl. Biochem. Biotechnol. 170 (7), 1676-1688. doi:10.1007/s12010-013-0306-z

Sanchez, E., Flores-Ortiz, R., Alvarenga, V., and Eble, J. (2017). Direct Fibrinolytic Snake Venom Metalloproteinases Affecting Hemostasis: Structural, Biochemical Features and Therapeutic Potential. Toxins 9 (12), 392. doi:10. 3390/toxins9120392

Sawhney, P., Kumar, S., Maheshwari, N., Guleria, S., Dhar, N., Kashyap, R., et al. (2016). Site-Specific Thiol-Mediated PEGylation of Streptokinase Leads to Improved Properties with Clinical Potential. Curr. Pharm. Des. 22 (38), 5868-5878. doi:10.2174/1381612822666160204120547

Sazonova, I. Y., Robinson, B. R., Gladysheva, I. P., Castellino, F. J., and Reed, G. L. (2004). a Domain Deletion Converts Streptokinase into a Fibrin-Dependent Plasminogen Activator through Mechanisms Akin to Staphylokinase and Tissue Plasminogen Activator. J. Biol. Chem. 279 (24), 24994-25001. doi:10. 1074/jbc.M400253200

Sharma, C., Salem, G. E. M., Sharma, N., Gautam, P., and Singh, R. (2020). Thrombolytic Potential of Novel Thiol-Dependent Fibrinolytic Protease from Bacillus cereus RSA1. Biomolecules 10 (1), 3. doi:10.3390/biom10010003

Sharmila, G. R., and Venkateswaran, G. (2017). Protective Effect of Bacillopeptidase CFR5 from Bacillus subtilis CFR5 on Cerulein-Induced Pancreatitis. Biochem. Biophysical Res. Commun. 491 (2), 455-462. doi:10. 1016/j.bbrc.2017.07.054

Shirasaka, N., Naitou, M., Okamura, K., Fukuta, Y., Terashita, T., and Kusuda, M. (2012). Purification and Characterization of a Fibrinolytic Protease from Aspergillus oryzae KSK-3. Mycoscience 53 (5), 354-364. doi:10.1007/S10267011-0179-3

Shukor, N. A. A., Amid, A., Ismail, M., and Abd Samad, N. S. (2015). Isolation of Thermotolerant Bacteria Producing Fibrinolytic Enzyme. Jurnal Teknologi 77 (25), 83-87. doi:10.11113/jt.v77.6744
Silva, G. M. d. M. e., Bezerra, R. P., Teixeira, J. A., Silva, F. O., Correia, J. M., Porto, T. S., et al. (2016). Screening, Production and Biochemical Characterization of a New Fibrinolytic Enzyme Produced by Streptomyces sp. (Streptomycetaceae) Isolated from Amazonian Lichens. Acta Amaz. 46, 323-332. doi:10.1590/18094392201600022

Silva, G. M. M., Teixeira, J. A., Porto, T. S., Lima-Filho, J. L., Porto, A. L. F., et al. (2015). Fibrinolytic Protease Production by New Streptomyces Sp. DPUA 1576 from Amazon Lichens. Electron. J. Biotechnol. 18, 16-19. doi:10.1016/j.jbt. 2014.11.001

Silva, P. E. d. C. e., Barros, R. C. d., Albuquerque, W. W. C., Brandão, R. M. P., Bezerra, R. P., and Porto, A. L. F. (2018). In Vitro Thrombolytic Activity of a Purified Fibrinolytic Enzyme from Chlorella vulgaris. J. Chromatogr. B 1092, 524-529. doi:10.1016/j.jchromb.2018.04.040

Siritapetawee, J., Thumanu, K., Sojikul, P., and Thammasirirak, S. (2012). A Novel Serine Protease with Human Fibrino(geno)lytic Activities from Artocarpus heterophyllus Latex. Biochim. Biophys. Acta 1824 (7), 907-912. doi:10.1016/j. bbapap.2012.05.002

Sobel, G. W., Mohler, S. R., Jones, N. W., Dowdy, A. B. C., and Guest, M. M. (1952). Urokinase, an Activator of Plasma Profibrinolysin Extracted from Urine. Am. J. Physiol. 171, 768.

SolokaMabika, F. A., Nguimbi, E., Kayath, A. C., and Ahombo, G. (2020). Molecular Characterization of Bacillus-Genus Bacteria with Fibrinolytic Potential Isolated from Squashes FNTETEE in Brazzaville in the Republic of Congo. Am. J. Microbiol. Res. 8 (1), 7-18. doi:10.12691/ajmr-8-1-2

Stam, J., de Bruijn, S. F., and deVeber, G. (2002). Anticoagulation for Cerebral Sinus Thrombosis. Cochrane Database Syst. Rev. (4), CD002005. doi:10.1002/ 14651858.CD002005

Stephani, L., Tjandrawinata, R. R., Afifah, D. N., Lim, Y., Ismaya, W. T., and Suhartono, M. T. (2017). Food Origin Fibrinolytic Enzyme with Multiple Actions. HAYATI J. Biosci. 24 (3), 124-130. doi:10.1016/j.hjb.2017. 09.003

Sumi, H., Hamada, H., Tsushima, H., Mihara, H., and Muraki, H. (1987). A Novel Fibrinolytic Enzyme (Nattokinase) in the Vegetable Cheese Natto; A Typical and Popular Soybean Food in the Japanese Diet. Experientia 43 (10), 1110-1111. doi:10.1007/BF01956052

Swan, D., Loughran, N., Makris, M., and Thachil, J. (2020). Management of Bleeding and Procedures in Patients on Antiplatelet Therapy. Blood Rev. 39, 100619. doi:10.1016/j.blre.2019.100619

Syahbanu, F., Kezia, E., Puera, N., Giriwono, P. E., Tjandrawinata, R. R., and Suhartono, M. T. (2020). Fibrinolytic Bacteria of Indonesian Fermented Soybean: Preliminary Study on Enzyme Activity and Protein Profile. Food Sci. Technol. 40, 458-465. doi:10.1590/fst.23919

Taneja, K., Bajaj, B. K., Kumar, S., and Dilbaghi, N. (2017). Production, Purification and Characterization of Fibrinolytic Enzyme from Serratia sp. KG-2-1 Using Optimized media. 3 Biotech 7 (3), 184. doi:10.1007/ s13205-017-0808-4

Taneja, K., Kumar Bajaj, B., Kumar, S., and Dilbaghi, N. (2019). Process Optimization for Production and Purification of Novel Fibrinolytic Enzyme from Stenotrophomonas sp. KG-16-3. Biocatal. Biotransform. 37 (2), 124-138. doi:10.1080/10242422.2018.1504925

Tatli, E., Ozcelik, F., and Aktoz, M. (2009). Plasma Fibrinogen Level May Predict Critical Coronary Artery Stenosis in Young Adults with Myocardial Infarction. Cardiol. J. 16 (4), 317-320.

Tharp, A. C., Laha, M., Panizzi, P., Thompson, M. W., Fuentes-Prior, P., and Bock, P. E. (2009). Plasminogen Substrate Recognition by the StreptokinasePlasminogen Catalytic Complex is Facilitated by Arg253, Lys256, and Lys257 in the Streptokinase $\beta$-Domain and Kringle 5 of the Substrate. J. Biol. Chem. 284 (29), 19511-19521. doi:10.1074/jbc.M109.005512

Thokchom, S., and Joshi, S. R. (2014). Screening of Fibrinolytic Enzymes from Lactic Acid Bacterial Isolates Associated with Traditional Fermented Soybean Foods. Food Sci. Biotechnol. 23 (5), 1601-1604. doi:10.1007/s10068-014-0217-y

Vadla, P. K., Tummuru, M., and Kumar, D. (2019). Purification and Characterization of Recombinant Streptokinase Expressed in E. coli from Streptococcus equisimilis with N-Terminal Methionine. Jurnal Teknologi Laboratorium 8 (1), 8-17. doi:10.29238/teknolabjournal.v8i1.153

Vaidya, B., Agrawal, G. P., and Vyas, S. P. (2011). Platelets Directed Liposomes for the Delivery of Streptokinase: Development and Characterization. Eur. J. Pharm. Sci. 44 (5), 589-594. doi:10.1016/j.ejps.2011.10.004 
Velumani, S. (2016). Isolation, Screening, Characterization and Production of Fibrinolytic Enzyme from Marine Microorganism. Int. J. Adv. Res. 2 (2), 2395-4396.

Verhamme, I. M., and Bock, P. E. (2014). Rapid Binding of Plasminogen to Streptokinase in a Catalytic Complex Reveals a Three-Step Mechanism. J. Biol. Chem. 289 (40), 28006-28018. doi:10.1074/jbc.M114.589077

Verma, M. K., and Pulicherla, K. (2017). Broad Substrate Affinity and Catalytic Diversity of Fibrinolytic Enzyme from Pheretima Posthumous-Purification and Molecular Characterization Study. Int. J. Biol. Macromol. 95, 1011-1021. doi:10.1016/j.ijbiomac.2016.10.090

Vijayaraghavan, P., Arasu, M. V., Anantha Rajan, R., and Al-Dhabi, N. A. (2019). Enhanced Production of Fibrinolytic Enzyme by a New Xanthomonas Oryzae IND3 Using Low-Cost Culture Medium by Response Surface Methodology. Saudi J. Biol. Sci. 26 (2), 217-224. doi:10.1016/j.sjbs.2018.08.029

Vijayaraghavan, P., Arun, A., Vincent, S. G. P., Arasu, M. V., and Al-Dhabi, N. A. (2016a). Cow Dung is a Novel Feedstock for Fibrinolytic Enzyme Production from Newly Isolated Bacillus sp. IND7 and its Application in In Vitro Clot Lysis. Front. Microbiol. 7, 361. doi:10.3389/fmicb.2016.00361

Vijayaraghavan, P., and Prakash Vincent, S. G. (2015). A Low Cost Fermentation Medium for Potential Fibrinolytic Enzyme Production by a Newly Isolated Marine Bacterium, Shewanella sp. Ind20. Biotechnol. Rep. 7, 135-142. doi:10. 1016/j.btre.2015.06.005

Vijayaraghavan, P., Prakash Vincent, S. G., Valan Arasu, M., and Al-Dhabi, N. A. (2016b). Bioconversion of Agro-Industrial Wastes for the Production of Fibrinolytic Enzyme from Bacillus halodurans IND18: Purification and Biochemical Characterization. Electron. J. Biotechnol. 20, 1-8. doi:10.1016/j. ejbt.2016.01.002

Vijayaraghavan, P., Rajendran, P., Prakash Vincent, S. G., Arun, A., Abdullah AlDhabi, N., Valan Arasu, M., et al. (2017). Novel Sequential Screening and Enhanced Production of Fibrinolytic Enzyme by Bacillus sp. IND12 Using Response Surface Methodology in Solid-State Fermentation. Biomed. Res. Int. 2017, 3909657. doi:10.1155/2017/3909657

Vijayaraghavan, P., and Vincent, S. G. P. (2014). Statistical Optimization of Fibrinolytic Enzyme Production by Pseudoalteromonas Sp. IND11 Using Cow Dung Substrate by Response Surface Methodology. Springerplus 3, 60. doi:10.1186/2193-1801-3-60

Wander, G. S., and Chhabra, S. T. (2013). Critical Analysis of Various Drugs Used for Thrombolytic Therapy in Acute Myocardial Infarction. Med. Updat 23, 109-116.

Wang, C. T., Ji, B. P., Li, B., Nout, R., Li, P. L., Ji, H., et al. (2006). Purification and Characterization of a Fibrinolytic Enzyme of Bacillus subtilis DC33, Isolated from Chinese Traditional Douchi. J. Ind. Microbiol. Biotechnol. 33 (9), 750-758. doi:10.1007/s10295-006-0111-6

Wang, C., Wang, F., Li, M., Tang, Y., Zhang, J. P., Gui, L. L., et al. (2004). Structural Basis for Broad Substrate Specificity of Earthworm Fibrinolytic Enzyme Component A. Biochem. Biophys. Res. Commun. 325 (3), 877-882. doi:10. 1016/j.bbrc.2004.10.113

Wang, S.-L., Wu, Y.-Y., and Liang, T.-W. (2011). Purification and Biochemical Characterization of a Nattokinase by Conversion of Shrimp Shell with Bacillus Subtilis TKU007. New Biotechnol. 28 (2), 196-202. doi:10.1016/j.nbt.2010. 09.003

Wei, X., Luo, M., Xu, L., Zhang, Y., Lin, X., Kong, P., et al. (2011). Production of Fibrinolytic Enzyme from Bacillus amyloliquefaciens by Fermentation of
Chickpeas, with the Evaluation of the Anticoagulant and Antioxidant Properties of Chickpeas. J. Agric. Food Chem. 59 (8), 3957-3963. doi:10. 1021/jf1049535

Weisel, J. W., and Litvinov, R. I. (2017). Fibrin Formation, Structure and Properties Fibrous Proteins: Structures and Mechanisms. Cham, Switzerland: Springer, 405-456.

Weng, Y., Yao, J., Sparks, S., and Wang, K. Y. (2017). Nattokinase: an Oral Antithrombotic Agent for the Prevention of Cardiovascular Disease. Int. J. Mol. Sci. 18 (3), 523. doi:10.3390/ijms 18030523

Wu, R., Chen, G., Pan, S., Zeng, J., and Liang, Z. (2019). Cost-Effective Fibrinolytic Enzyme Production by Bacillus subtilis WR350 Using Medium Supplemented with Corn Steep Powder and Sucrose. Sci. Rep. 9 (1), 1-10. doi:10.1038/s41598019-43371-8

Xavier, M. A., Tirloni, L., Torquato, R., Tanaka, A., Pinto, A. F., Diedrich, J. K., et al. (2019). Blood Anticlotting Activity of a Rhipicephalus Microplus Cathepsin L-Like Enzyme. Biochimie 163, 12-20. doi:10.1016/j.biochi.2019.04.025

Xin, X., Ambati, R. R., Cai, Z., and Lei, B. (2018). Purification and Characterization of Fibrinolytic Enzyme from a Bacterium Isolated from Soil. 3 Biotech 8 (2), 90. doi:10.1007/s13205-018-1115-4

Yao, Z., Kim, J. A., and Kim, J. H. (2019). Characterization of a Fibrinolytic Enzyme Secreted by Bacillus Velezensis BS2 Isolated from Sea Squirt Jeotgal. J. Microbiol. Biotechnol. 29 (3), 347-356. doi:10.4014/jmb.1810. 10053

Yao, Z., Kim, J. A., and Kim, J. H. (2018). Gene Cloning, Expression, and Properties of a Fibrinolytic Enzyme Secreted by Bacillus pumilus BS15 Isolated from Gul (Oyster) Jeotgal. Biotechnol. Bioproc. Eng. 23 (3), 293-301. doi:10.1007/s12257018-0029-7

Yatagai, C., Maruyama, M., Kawahara, T., and Sumi, H. (2007). NattokinasePromoted Tissue Plasminogen Activator Release from Human Cells. Pathophysiol. Haemost. Thromb. 36 (5), 227-232. doi:10.1159/000252817

Yuan, J., Yang, J., Zhuang, Z., Yang, Y., Lin, L., and Wang, S. (2012). Thrombolytic Effects of Douchi Fibrinolytic Enzyme from Bacillus subtilis LD-8547 In Vitro and In Vivo. BMC Biotechnol. 12 (1), 36. doi:10.1186/1472-6750-12-36

Yusuf, S., Joseph, P., Rangarajan, S., Islam, S., Mente, A., Hystad, P., et al. (2020). Modifiable Risk Factors, Cardiovascular Disease, and Mortality in 155722 Individuals from $21 \mathrm{High}$-Income, Middle-Income, and Low-Income Countries (PURE): A Prospective Cohort Study. Lancet 395 (10226), 795-808. doi:10. 1016/S0140-6736(19)32008-2

Zeng, W., Li, W., Shu, L., Yi, J., Chen, G., and Liang, Z. (2013). Non-Sterilized Fermentative Co-Production of $\operatorname{Poly}(\gamma$-Glutamic Acid) and Fibrinolytic Enzyme by a Thermophilic Bacillus subtilis GXA-28. Bioresour. Technol. 142, 697-700. doi:10.1016/j.biortech.2013.05.020

Conflict of Interest: The authors declare that the research was conducted in the absence of any commercial or financial relationships that could be construed as a potential conflict of interest.

Copyright (c) 2021 Altaf, $W u$ and Kasim. This is an open-access article distributed under the terms of the Creative Commons Attribution License (CC BY). The use, distribution or reproduction in other forums is permitted, provided the original author(s) and the copyright owner(s) are credited and that the original publication in this journal is cited, in accordance with accepted academic practice. No use, distribution or reproduction is permitted which does not comply with these terms. 